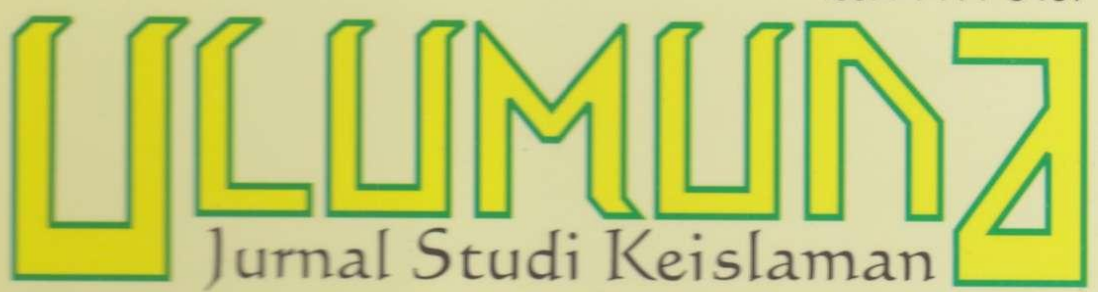

Volume 16 • Nomor 2• Desember 2012

Terakreditası B; SK Dirjen Dikti Kemdikbud Nomor: 56/DIKTI/Kep/2012, Tanggal 24 Juli 2012

REORIENTASI KAJIAN TEOLOGI ISLAM: IKHTIAR KONTRIBUTIF ATASI PROBLEM KEKINIAN Muhammad Rusli

PERGOLAKAN TEOLOGI SYIAH-SUNNI: MEMBEDAH POTENSI INTEGRASI DAN DISINTEGRASI

Slamet Mulyono MEnimbang KontorVERSI PEMAKNAAN KONSEP AHL AL-KITĀB DALAM AL-QUR'AN Zulyadain ECOTHEOLOGY:

TEOLOGI KONSTRUKTIF ATASI KRISIS LINGKUNGAN Abdul Quddus AKU DALAM TUHAN: IMPLIKASI TEOLOGI PROSES PADA ERA KONTEMPORER Suhermanto la'far PERgulatan TEOLOGI SALAFI DALAM MAINSTREAM KEBERAGAMAAN MASYARAKAT SASAK Faizah STUDI KOMPARATIF KONSEP KETUHANAN ISLAM DAN AGAMA ADAM PADA KOMUNITAS SAMIN Mohammad Rosyid KEGALAUAN IDENTITAS:

Dilema Hubungan Komunitas Muslim dan Hindu di BalI Siti Raudhatul Jannah 



\section{DAFTAR ISI}

\section{Pedoman Transliterasi}

223-244 • Muhammad Rusli,

"Reorientasi Kajian Teologi Islam:

Ikhtiar Kontributif Atasi Problem Kekinian"

245-278 • Slamet Mulyono,

"Pergolakan Teologi Syiah-Sunni:

Membedah Potensi Integrasi dan Disintegrasi"

279-310•Zulyadain,

"Menimbang Kontorversi Pemaknaan

Konsep Ahl Al-Kitāb Dalam Al-Qur'an"

311-346 • Abdul Quddus,

"Ecotheology:

Teologi Konstruktif Atasi Krisis Lingkungan"

347-374 • Suhermanto Ja'far,

"Aku dalam Tuhan:

Implikasi Teologi Proses pada Era Kontemporer"

375-402 • Faizah,

"Pergulatan Teologi Salafi

dalam Mainstream Keberagamaan Masyarakat Sasak"

403-442• Mohammad Rosyid, "Studi Komparatif Konsep Ketuhanan Islam

dan Agama Adam pada Komunitas Samin"

443-464 • Siti Raudhatul Jannah,

"Kegalauan Identitas: Dilema Hubungan

Komunitas Muslim dan Hindu di Bali"

INDEKS

APENDIKS 


\section{PEDOMAN TRANSLITERASI}

\begin{tabular}{|c|c|c|c|c|c|c|}
\hline 1 & $=$ & $\mathbf{a}$ & & $\dot{\varepsilon}$ & $=$ & $\mathrm{g}$ \\
\hline ب & $=$ & b & & ف & $=$ & f \\
\hline$ت$ & $=$ & $\mathbf{t}$ & & ق & $=$ & $q$ \\
\hline$\dot{H}$ & $=$ & th & & ك5 & $=$ & $\mathbf{k}$ \\
\hline ج & $=$ & $\mathfrak{j}$ & & J & $=$ & 1 \\
\hline$\tau$ & $=$ & ha & & م & $=$ & $\mathbf{m}$ \\
\hline$\dot{\tau}$ & $=$ & kh & & ن & $=$ & $\mathbf{n}$ \\
\hline د & $=$ & d & & و & $=$ & $\mathbf{w}$ \\
\hline ذ & $=$ & dh & & ○ & $=$ & $\mathbf{h}$ \\
\hline J & $=$ & $\mathbf{r}$ & & $\varepsilon$ & $=$ & , \\
\hline j & $=$ & $\mathbf{z}$ & & ي & $=$ & $\mathbf{y}$ \\
\hline 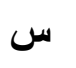 & $=$ & s & & & & \\
\hline ش ش & $=$ & sh & \multicolumn{4}{|c|}{ Untuk Madd dan Diftong } \\
\hline ص & $=$ & $\mathbf{s}$ & T & $=$ & \multicolumn{2}{|c|}{$\bar{a}$ (a panjang) } \\
\hline 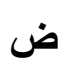 & $=$ & d & إي & $=$ & \multicolumn{2}{|c|}{$\overline{1}$ (i panjang) } \\
\hline b & $=$ & $\mathbf{t}$ & أو & $=$ & \multicolumn{2}{|c|}{$\bar{u}$ (u panjang) } \\
\hline ظ & $=$ & $\mathrm{z}$ & او & $=$ & \multicolumn{2}{|c|}{ aw } \\
\hline$\varepsilon$ & $=$ & 6 & أي & $=$ & \multicolumn{2}{|c|}{ ay } \\
\hline
\end{tabular}

Contoh penulisan dengan transliterasi:

اعوذ بالله من الشيطان الرجيم (a'üdhu bi al-Lāh min al-shaytān al-rajìm);

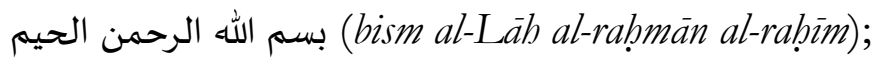

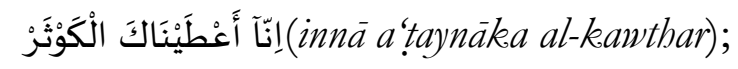

فَصََلِّ لِرَبِّكَ وَانْحَرْ (fasalli lirabbika wanharar);

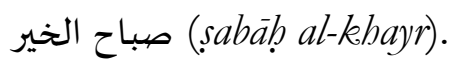




\title{
STUDI KOMPARATIF KONSEP KETUHANAN ISLAM DAN AGAMA ADAM PADA KOMUNITAS SAMIN
}

\author{
Mohammad Rosyid \\ (Sekolah Tinggi Agama Islam Negeri [STAIN] Kudus \\ Email: mrosyid72@yahoo.co.id)
}

Abstract: One of the problems that disturb the harmony between religious communities is a lack of understanding of the majority (mainstream) religion about the local religion, and vice versa. This article aims to develop such inter-religious understanding by comparing between Islam and the religion of Adam, a local religion of Samin community. The comparative study was made within the scope of the concept of God in both religions. This study found that the understanding between Islam the religion of Adam about the concept of God is essential in common. God called Allah (in Islam) and Yai (in the religion of Adam) are equally perceived as condescendent, an only single power, and the Almighty. Both communities also share Adam as the first man in the world. So, it is not proportional if the public ridicule Samin community with atheist stigma.

Abstrak: Salah satu problem yang mengganggu keharmonisan antar komunitas beragama adalah kurangnya pemahaman pemeluk agama mayoritas (mainstream) di suatu negara tentang agama lokal, dan demikian pula sebaliknya. Artikel ini bertujuan untuk membangun kesalingpahaman antar pemeluk agama itu dengan melakukan kaji banding antara agama Islam dengan agama Adam, sebuah agama lokal komunitas Samin. Kaji banding itu dilakukan dalam lingkup konsep ketubanan dalam dua agama itu. Kajian ini menemukan babwa pemahaman antara Islam dengan agama Adam tentang konsep Tuhan memiliki kesamaan secara esensial. Tuban yang disebut dengan Allah (dalam Islam) dan Yai (dalam agama Adam) sama-sama dipersepsikan sebagai tempat berlindung, kekuatan tunggal, dan Zat Yang Maha segalagalanya. Kedua komunitas juga sama dalam memandang Adam sebagai manusia yang pertama di dunia. Dengan adanya pemahaman itu maka tidak proporsional lagi jika publik mengolok-olok komunitas Samin dengan stigma ateis.

Keywords: konsep ketubanan, Tuhan, agama Islam, komunitas Samin, agama Adam, studi komparatif. 
ESENSI orang beragama adalah mengakui dan memiliki Tuhan. Memahami Tuhan dalam kajian ilmiah agar tergambarkan dengan luas dan variatif, perlu mengkaji konsep pemeluk agama lain agar saling memahami antarpemeluk agama. Pemahaman tersebut merupakan modal dasar manusia menuju kehidupan yang pluralis dan toleran dalam beragama. Pernyataan tersebut didasari realitas bahwa tersulutnya konflik intern atau antarpemeluk agama mayoritas karena tidak tahu konsep ajaran agama bagi pemeluk agama lain dan merasa benar sendiri.

Agama Adam bagi komunitas Samin dalam realitanya tidak mendapatkan respon positif secara administratif oleh pemerintah karena agama Adam dikategorikan aliran kepercayaan. Hal ini terbukti dengan pengosongan kolom agama dalam KTP warga Samin di Kudus, sesuai amanat UU Nomor 23 Tahun 2003 tentang Administrasi Kependudukan Pasal 61 (2) bagi penduduk yang agamanya belum diakui sebagai agama sesuai dengan ketentuan perundangan atau bagi penghayat kepercayaan (kolom agama dalam KTP) tidak diisi, tetapi tetap dilayani dan dicatat dalam database kependudukan. Dengan demikian, pencantuman agama dalam KTP diperuntukkan bagi warga negara yang agamanya tertera dalam perundangan ${ }^{1}$.

Naskah ini membandingkan konsep agama Adam dengan Islam tentang esensi Tuhan. Agama Adam dipeluk oleh komunitas Samin, kini berada di Bojonegoro (Jawa Timur), Blora, Pati, Kudus, dan Purwodadi (Jawa Tengah). Adapun konsep Tuhan dalam Islam berpijak pada pesan surat al-Ikhlas. Surat al-Ikhlaṣ mengulas konsep Tuhan secara eksplisit dengan menandaskan keesaan Tuhan. Mengapa membandingkan Samin dengan Islam dalam hal ketuhanan? Harapannya potret Samin dapat dipahami publik, sehingga tidak terjadi salah paham terhadap jati diri Samin. Anggapan bahwa Samin adalah komunitas yang pembangkang pembangunan, tertutup, terbelakang, bodoh, miskin, dan tak bertuhan, realitasnya kini adalah sebaliknya.

1PP 55 Tahun 2007 tentang Pendidikan Agama dan Pendidikan Keagamaan Pasal 9 (1) pendidikan keagamaan meliputi pendidikan keagamaan Islam, Kristen, Katolik, Hindu, Buddha, dan Konghucu. 


\section{Eksistensi Komunitas Samin}

Komunitas Samin (Sedulur Sikep) muncul ketika masa pendudukan Belanda di Jawa. Hal itu diawali ketika Raden Surowijoyo, anak seorang Bupati Tulungagung (Raden Adipati Mas Suryo [RAMS] Brotodiningrat Kusumaningrum) ingin bergabung (lelono/ayam alas) dengan masyarakat, meninggalkan kadipaten menuju Desa Plosokediren, Kecamatan Randublatung, Kabupaten Blora, Jawa Tengah melawan Belanda. RAMS Brotodiningrat memerintah Kadipaten Sumoroto (sekarang wilayah Kabupaten Tulungagung, Jawa Timur $)^{2}$. Menyatunya R. Surowijoyo dengan warga pinggiran dan bawahan sebagai wujud jumbuhing gusti-kaulo (bersatunya raja dengan rakyat). Perjalanan berikutnya, Ki Surowijoyo melawan Belanda karena arogansi Belanda merampas tanah rakyat tanpa prosedur yang benar. Gerakan komunitas Samin antara lain merampok harta warga yang kaya karena mengikuti Belanda dan hasil perampokan dibagikan pada masyarakat miskin. Perjuangan Ki Surowijoyo diteruskan oleh putranya, Raden Kohar atau Samin Anom atau Ki Surosentiko yang dilahirkan pada tahun 1859 di Desa Plosokediren. Ki Surosentiko membuat desa baru (babat alas) sehingga menjadi Desa Plosodiren atau Plosokediren, Kecamatan Randublatung, Kabupaten Blora yang semula di tengah hutan. Akibat perlawanan warga Samin terhadap Belanda, maka Ki Samin disiksa Belanda dengan ditumbuk (dideplok) di lesung, tetapi khalayak melihat dalam waktu yang sama Ki Samin berada di rumahnya karena keampuhannya. Ada juga yang berkeyakinan, pada kesempatan lain, Ki Samin berjalan di atas air, sehingga ketika disiksa Belanda dimasukkan dalam drum dan dibuang ke laut pun masih hidup. Pada suatu ketika, Ki Samin berpesan pada anaknya yang bernama Yongnyah bahwa dirinya akan diperlakukan lebih kejam oleh Belanda. Prediksi itu terjadi, ia dipaksa Belanda meninggalkan Blora dan akhirnya diasingkan ${ }^{3}$. Sebelum Ki Samin wafat, ia berpesan pada

2Pramugi Prawiro Wijoyo, Giyare Kaki Samin Surosentiko Bab Lakon 'Sikep’ Winongko Paugerane Urip Kang Demunung (ttp: tp, 2011), 1.

3Versi wafatnya Ki Samin, antara lain: (1) dibuang Belanda di Digul, Irian Jaya dan selanjutnya diasingkan di Sawahlunto, Padang, Sumatra Barat. Hal itu terjadi karena pada tahun 1890 mengembangkan ajaran Samin di 
pengikutnya Engkrek dan Brawok supaya: (1) mempertahankan agama yang dipeganginya yakni Adam., (2) menjumpai Ki Surokidin (menantu Ki Samin Surosentiko) di Desa Tanduran, Blora, (3) Ki Samin berwasiat, meskipun ia tertinggal di pengasingan, tetapi dirinya pun akan pulang juga ke tanah Jawa dengan sesorah mbesok ojo samar karo aku, keno pangkling rupane, ojo pangkling suarane (besok jangan lupa denganku, boleh lupa wajahku, jangan lupa suaraku). Istilah Samin merupakan julukan bagi masyarakat yang memegangi ajaran Ki Samin Surosentiko, meskipun orang Samin lebih senang dipanggil sedulur sikep. ${ }^{4}$

Desa Klopodhuwur, Blora, Jateng. Tahun 1905 setelah banyaknya pengikut, melawan Belanda; (2) Tahun 1907 Ki Samin diculik Belanda dan dibawa ke Rembang, Jateng beserta 8 pengikutnya, selanjutnya dibuang di Sawahlunto, Padang, Sumatera Barat, wafat 1914 sebagai tawanan; (3) Pengikut ajaran sikep ditekan Belanda karena tidak mau membayar pajak dan tidak mau kerja paksa. Akhirnya oleh Belanda Ki Samin dibuang ke Sumatera Barat dan meninggal pada tahun 1914 dalam status tahanan, dan (4) Menurut Santoso (tokoh Samin di Desa Larekrejo, Kudus, Jateng) Ki Samin wafat di Sawahlunto tahun 1602 Saka, 1676 M atau 1599 tahun Jawa. Dibuangnya Ki Samin beserta kerabat dan pengikutnya yakni Karjani, Singotirto, Brawok, dan Engkrek.Tetapi semua dapat kembali lagi ke Jawa (Blora) kecuali Ki Samin Surosentiko.

4Istilah Samin karena bertendensi negatif, sehingga kelompok Samin menamakan diri "Sedulur Sikep" dengan beberapa pertimbangan. Pertama, mendapat tekanan Belanda, dipimpin seorang petani Ki Samin Surosentiko (Raden Kohar), pujangga Jawa pesisiran pasca-Ronggowarsito menyamar sebagai petani menghimpun kekuatan melawan Belanda. Tahun 1890 mengembangkan ajaran Samin di Desa Klopoduwur, Banjarejo, Blora, Jawa Tengah, Tahun 1905 setelah banyak pengikutnya ia melawan Belanda. Kedua, karena tindakan Samin menentang aparat desa tidak membayar pajak dan memisahkan diri dengan masyarakat umum, penolakan itu muncul kata nyamin. Ketiga, sebagai sarana menjalin komunikasi dengan sesama penganutnya dan pihak yang membutuhkan informasi sebagai wujud simbolisasi penamaan diri. Secara filosofi bahwa munculnya kelahirankehidupan manusia berawal dari proses "sikep" atau berdekapan (Jawa: bentuk hubungan seksual suami-istri) atau proses menanak nasi secara tradisional adalah melalui proses "nyikep". Keempat, analisis Amrih Widodo, kata 'sikep' merupakan cara melawan atau menghindari penamaan dengan kata 'samin' akibat konotasi negatif yang dilekatkan pada kata 'Samin' selama bertahun-tahun. Naskah ini menggunakan istilah "Samin", tidak "Sedulur Sikep" dengan pertimbangan popularitas istilah. Moh. Rosyid, Samin Kudus Bersahaja di Tengah Asketisme Lokal (Yogyakarta: Pustaka Pelajar, 2008). 
Bila ditelaah dari aspek sejarah, Samin merupakan istilah yang bernuansa politis dan lebih tersohor sebagai pembangkang sehingga keberadaannya "dibidik" Belanda karena action-nya (1) menentang penjajah dengan gerakan "khas" berupa tak membayar pajak, karena hasil pajak tidak untuk pembangunan masyarakat tetapi untuk Belanda, (2) tidak ikut gotong-royong bersama (gugur-gunung) karena terbangunnya jalan untuk memperlancar transportasi Belanda, (3) gerakan "berbahasa jujur” untuk mengelabui penjajah dengan 'kiratabasa'. Gerakan, cara, dan bentuknya bergeser secara perlahan-lahan hingga kini menjadi taat pembangunan karena berbagai faktor. Eksistensi ajaran Samin disebarluaskan oleh tokoh (botob) Samin dengan mendatangi setiap daerah yang dikunjungi dengan strategi paseduluran yakni memperkenalkan dan mengokohkan tali persaudaraan. Hal tersebut jika mendapatkan respon positif terjadi kesinambungan interaksi. Leluhur Samin pada masa lalu dalam beranjangsana dengan jalan kaki antardaerah yang dikunjungi karena kondisi alam dan belum adanya saranaprasarana transportasi seperti saat ini $^{5}$. Akhirnya keberadaan ajaran Samin diterima oleh warga di Pati dan Kudus, Jawa Tengah hingga kini. ${ }^{6}$

5Pengakuan Sukari (sesepuh Samin Desa Kutuk, Undaan, Kudus) bahwa Ki Samin datang di rumah orangtuanya menenteng sandal jepit jika musim hujan.

'Proses penyebaran ajaran Samin dari Blora ke Pati hingga di Kudus karena beberapa faktor, (1) Blora, Rembang, Pati, dan Kudus, secara geografis berdekatan. Warga Samin di wilayah Pati berada di Dukuh Bombong, Ngawen, Galiran, dan Sukalila hingga kini. Samin di Kudus eksis di Desa Larekrejo, Kutuk, Karangrowo, ketiganya di Kecamatan Undaan, (2) faktor geografis desa 'Samin' berada di pedesaan, sesuai “teori gelombang dalam bejana" semakin jauh dari titik gelombang, getaran gelombang makin tipis dan mengecil, sehingga imbas pembangunan "sedikit" terbatas. Jika dibandingkan dengan wilayah yang dekat dengan pemerintahan, (3) pembangunan bidang keagamaan kurang maksimal di kampung 'Samin' jika dibandingkan wilayah Kudus yang memiliki beberapa pesantren) dan terdapat tokoh kharismatik yang membidangi ilmu agama, (4) kehidupan masyarakat di sekitar warga Samin berada adalah permisif, maksudnya, menerima (responsif) jika terdapat sekte atau komunitas lain asalkan tidak mengganggu kenyamanan sosial. Penyebaran ajaran Samin dari Blora, Pati, hingga di Kudus terdapat beberapa versi: pertama, Samin di Kudus berasal 


\section{Stigma negatif oleh publik tertuju pada masyarakat Samin} karena komunitas Samin menolak membayar pajak masa penjajahan karena berprinsip bahwa pajak (saat itu) tidak untuk kepentingan pembangunan anak negeri, tetapi memperkaya kolonial, meski kini telah menaati peraturan pemerintah ${ }^{7}$.

dari Desa Klopoduwur Kabupaten Blora, Jawa Tengah sejak Tahun 1890, ketika Sosar, Radiwongso, Amat Ngargono, dan Proyongaden bertemu dengan Surondiko. Sumber sejarah tak menyajikan tahun kedatangan dan penyebarannya. Kedua, ajaran Samin berasal dari Desa Randublatung, Blora dimotori oleh Surowijoyo, diteruskan putranya Surosentiko bertemu Suronggono (warga Samin Pati) dan Sosar (warga Desa Kutuk), Radiwongso (warga Dukuh Kaliyoso Desa Karangrowo), Proyongaden (warga Desa Larekrejo), dan Amat Ngargo (warga Dukuh Mijen, Desa Bulungcangkring), sehingga muncul Samin di Kudus. Ketiga, ajaran Samin menyebar di Desa Kutuk, Kudus melalui Ki Samin Surowijoyo dari Randublatung, Blora, membawa kitab "Serat Jamus Kalimasada" berbahasa Jawa kuno berbentuk sekar macapat dan prosa (gancaran). Sumber ini tidak melengkapi data siapakah personil yang membawa kitab tersebut. Keempat, ekspansi dilakukan R.Kohar mengembangkan ajaran Samin ke berbagai wilayah untuk membangun pusat perlawanan terhadap Belanda. Kelima, ajaran Samin di Kudus tahun 1916 dibawa oleh pengikut Samin Surosentiko diawali kegagalan ekspansi di daerah Tuban. Kini ajaran Samin di Desa Kutuk diteruskan Sukari, di Dukuh Kaliyoso sebagai sesepuh adalah Wargono yang meneruskan ketokohan Sumar, dan di Desa Larekrejo sebagai sesepuhnya Santoso yang meneruskan ketokohan Sakam yang wafat tahun 2006. Jalur penerimaan ajaran Samin di Desa Larekrejo merupakan kiprah tokoh Samin dari Pati yakni Surosentiko, Surokidin, Proyongaden, yang diteruskan oleh Towijoyo, Kastohadi, dan Kasrani. Rosyid, Samin Kudus, 41.

${ }^{7}$ Penolakan terhadap aktivitas yang dilakukan penjajah Belanda oleh masyarakat Samin pada masa kini mengalami pergeseran pemahaman. Seperti sebagian telah sekolah formal (bagi warga Samin yang bertipologi ampeng-ampeng) dan membayar pajak (semua warga Samin, tanpa mengenal tipologi). Hal itu terjadi karena penafsirannya terhadap ajaran Samin dan instruksi leluhurnya. Penafsiran tersebut sangat dipengaruhi oleh tokoh (botob) yang dijadikan sumber fatwa. Peluang terjadinya perbedaan dalam memberikan ajaran kesaminan dari tokoh kepada warga Samin karena (i) ajaran diberikan melalui tradisi lisan (cerita lisan), (ii) setiap tokoh, dalam menerima ajaran Samin, bersumber dari tokohnya yang berbeda dalam hal substansi ajaran. Hal ini terjadi karena ciri tradisi lisan itu sendiri, dan (iii) penerima ajaran melalui tradisi lisan, dalam memahaminya sangat ditentukan oleh kemampuan penerima memahami pesan. Ketiga hal tersebut berdampak terhadap perilaku warga Samin dalam memegangi ajaran leluhurnya. 
Penolakan membayar pajak tersebut masih melekat pada pemahaman masyarakat non-Samin hingga kini karena didukung anggapan bahwa gerakan tarekat (agama) dan petani diwarnai perlawanan, seperti pemberontakan di Banjarmasin, Kalimantan Selatan (1859-1862), kasus Haji Rifa'i (Ripangi) dari Kalisalak, Batang, Jateng (1859), peristiwa Cianjur-Sukabumi (1885), pemberontakan petani Cilegon-Banten (1888), dan peristiwa Garut (1919). Realitas lainnya dalam konteks kini, masyarakat Samin perkawinannya tidak melibatkan KUA atau Kantor Catatan Sipil dengan dalih melaksanakan pesan leluhurnya. Hal ini bertentangan dengan UU Nomor 1 Tahun 1974 tentang Perkawinan. Di sisi lain, sebagian warga Samin tidak mendidik anaknya di lembaga pendidikan formal. Hal ini bertentangan dengan PP Nomor 47 Tahun 2008 tentang Wajib Belajar.

Asal-usul kata 'Samin', pertama, kata 'Samin' bermakna "sama" maksudnya, bersama-sama atau sama-sama membela negara melawan Belanda. Kata 'sama' atau 'Samin' juga bermakna "sami-sami amin" maksudnya jika semua setuju melawan penjajah maka perlawanan tersebut menandakan adanya dukungan dari sesamanya. Dengan kekompakan tersebut diharapkan diperoleh kesejahteraan hidup ${ }^{8}$. Kedua, diilhami nama tokoh komunitas Samin yakni Ki Samin Surosentiko9. Ki Samin bertalian darah dengan Ki Keti di Rajegwesi, Bojonegoro dan Pangeran Kusumoningayu berkuasa di Kabupaten Sumoroto (sekarang wilayah Kabupaten Tulungagung, Jawa Timur) sebagai pujangga Jawa pesisiran pasca-Ronggowarsito yang menyamar sebagai petani menghimpun kekuatan melawan Belanda. Ketiga, Kata 'Samin' bermakna Sami Wonge (sama orangnya) maksudnya, sesama manusia adalah bersaudara. Hal ini diilhami prinsip ajaran Samin yang mengedepankan aspek etika kemanusiaan,

${ }^{8}$ Hardjo Kardi, Riwayat Perjuangan Ki Samin Surosentiko (ttp: tp, 1996), 2.

${ }^{9}$ Sebutan untuk Ki Samin antara lain Ki Samin Surosentiko, Ki Samin Surondiko, Ki Samin Surontiko. Perbedaan pengucapan ini karena berdasarkan daya tangkap (pendengaran) warga Samin dalam menyebutkan nama leluhurnya. Ki Samin memiliki nama lain yakni Raden Surowidjojo (nama ketika tua), Raden Surontiko atau Raden Suratmoko atau Samin Anom (nama kecil). Ayah Ki Samin Surosentiko (Raden Surowijaya atau Samin sepuh) mengubah nama anaknya (R. Kohar) menjadi Samin Surosentiko, Samin merupakan nama yang bernafas wong cilik. 
tercermin dalam ajaran Samin. Keempat, Perjuangan Ki Surosentiko agar tidak terdeteksi oleh masyarakat bahwa dirinya adalah trah ningrat, ia menamakan dirinya 'Samin' yang bermakna sami-sami tiyange (sesama manusia) atau jika sesama manusia berarti bersaudara dan akhirnya dijuluki Ki Samin. Kelima, kata/nama Samin juga nama sebuah Suku di Jawa Tengah. Nama suku tersebut antara lain Samin, Jawa, Karimun, dan Kangean ${ }^{10}$. Keenam, Samin atau Saminisme adalah anggapan orang Jawa pesisir bagi komunitas yang hidup di daerah pinggiran ${ }^{11}$. Ketujuh, versi dongeng rakyat, kata Samin muncul sebelum Samin Surontiko ada. Tepatnya ketika masyarakat di lembah Sungai Bengawan Solo dari Suku Kalang (bekas para Brahmana, pendeta, dan sarjana Majapahit akhir pemerintahan Brawijaya V) yang menyingkir dari Majapahit ${ }^{12}$. Versi ketujuh bertolak belakang dengan anggapan lain bahwa keberadaan warga Samin di Bengawan Solo merupakan usaha R. Surowidjojo memperluas daerah perlawanan terhadap Belanda sejak tahun $1840^{13}$.

Penyebutan 'Samin' dipandang sensitif oleh publik yang mendeskriditkan Samin, bahkan masyarakat kini menganggapnya punah. Hal itu muncul karena Samin mengedepankan ke-diri-an, bukan untuk show of force (menampakkan kemampuan) di mata publik $^{14}$. Ketenaran bukan hobinya, mereka dipandang publik dengan kaca mata buram, tidak kooperatif karena tidak mau membayar pajak, enggan ikut ronda, suka membangkang, dan suka menentang. Hal itu di masa penjajah menjadi tabiatnya.

${ }^{10}$ Edi Sigar, Provinsi Jawa Tengah (Jakarta: Pustaka Delapratasa, 1998), 1.

${ }^{11}$ Suwardi Endraswara, Budi Pekerti dalam Budaya Jawa (Yogyakarta: Hanindita, 2003), 17.

${ }^{12}$ Soerjanto Sastroatmodjo, Masyarakat Samin Siapakah Mereka? (Yogyakarta: Narasi, 2003), 78.

13Sugeng Winarno, Samin: Ajaran Kebenaran yang Nyeleneb dalam Agama Tradisional Potret Kearifan Hidup Masyarakat Samin dan Tengger (Yogyakarta: LKiS, 2003), 56.

${ }^{14}$ Sebagaimana ungkapannya: ora seneng digunggung, ora serek di olo. Wong urip iku kudu: bener, rukun, eling marang sepodo-podo kanti laku seng ati-ati, eleng, waspodo, sabar, semeleh, lan seneng ati (Tak suka puja, tidak marah jika dicerca. Orang hidup harus: benar, rukun, memahami sesama. Perilakunya hati-hati, memahami diri, waspada, sabar, pasrah, dan berbahagia batin). 
Tetapi, kondisi sekarang, mayoritas telah menaati kebijakan pemerintah RI dalam bidang pembangunan ${ }^{15}$. Bahkan di masa Orde Baru, melepas 'baju' Samin (kawin dengan hukum negara yakni tercatat dalam surat nikah) dimeriahkan upacara perkawinan masal ${ }^{16}$.

Konteks masa kini, gerakan Samin masih memiliki kekhasan dan beraroma perlawanan terhadap pemerintah. Bagi Samin yang bertipe Dlejet/dledek bentuk perlawanannya berupa tidak memiliki Kartu Tanda Penduduk (KTP), tidak sekolah formal, kawin tidak menyertakan peran negara. Adapun bagi warga Samin yang bertipe amping-amping, gerakannya berupa sekolah formal, tetapi tidak mau menerima mata ajar agama 'pancasila', memiliki KTP, dan perkawinannya tidak menyertakan peran negara (KUA/Kantor Catatan Sipil) ${ }^{17}$.

${ }^{15} \mathrm{Hal}$ ini diawali karena adanya hubungan erat antara Ki Engkrek (leluhur warga Samin di Dukuh Karangpace, Desa Klopoduwur, Banjarejo, Blora). Hubungan tersebut diwujudkan ketika Ki Engkrek memiliki dua cincin yang berwarna merah-putih). Cincin tersebut diduga warga Samin mengilhami Bung Karno menentukan warna bendera kebangsaan. Adapun di wilayah Kabupaten Pati berupa simpatinya masyarakat Samin terhadap Bung Karno. Dibuktikan dengan menghadiri ketika Presiden Soekarno tahun 1945-an berorasi di alun-alun Kabupaten Pati, mengajak masyarakat dan komunitas Samin pantang menyerah melawan penjajah, ajakan tersebut diterima tokoh Samin. Imbas kehadiran tersebut, masyarakat Samin dianggap oleh publik, komunitas yang berhaluan nasionalis-komunis.

16Sebagaimana dilakukan 9 pasang warga Samin di Dukuh Kaliyoso, Desa Karangrowo, Kecamatan Undaan Kabupaten Kudus, tanggal 3 Januari 1997. Kompas, 7 Januari 1997.

${ }^{17}$ UU No.1/1974 tentang Perkawinan Pasal 2 (1) setiap perkawinan dicatat menurut peraturan perundangan yang berlaku. Samin di Dukuh Karangpace, Desa Klopoduwur, Kecamatan Banjarejo, Blora pasca G 30 S, perkawinannya dicatatkan di KUA. Warga Samin di Desa Larekrejo, Undaan, Kudus dan di Dukuh Bombong, Desa Baturejo, Sukolilo, Pati tak mengenal pencatatan pernikahan karena tidak diajarkan leluhurnya. Pasal 7 (1) perkawinan hanya diijinkan jika pihak pria (minimal) berumur 19 tahun dan pihak wanita (minimal) berumur 16 tahun. Perkawinan Samin tak mengenal batas maksimal dan minimal usia, hanya sesuai keinginannya. UU No.23/2006 tentang Adminduk, Pasal 34 (1) perkawinan yang sah menurut peraturan perundang-undangan wajib dilaporkan oleh penduduk kepada instansi pelaksana di tempat terjadinya perkawinan paling lambat 60 hari sejak tanggal perkawinan, (2) berdasarkan laporan sebagaimana ayat (1), pejabat pencatatan sipil mencatat register akta perkawinan dan menerbitkan 


\section{Ciri Masyarakat Samin}

Ajaran Samin diwariskan secara oral tradition (sabdo tanpo rapal, ajaran yang tak tertulis) berbentuk prinsip hidup dan pantangan hidup. Karakter khasnya adalah hidup di pedesaan dan sebagai petani, kekhasan inipun mengalami perubahan karena memenuhi kebutuhan hidupnya, seperti sebagian kecil menjadi tenaga kerja di luar pulau dan Tenaga Kerja Indonesia (TKI/TKW) sebagaimana terjadi pada warga Samin di Kudus dan Pati. Adapun pembeda antara komunitas Samin dengan non-Samin, pertama, warga Samin dalam perilaku berpijak dari prinsip ajaran Samin. Prinsip tersebut diwujudkan dalam berperilaku berupa etika, prinsip ajaran dan prinsip pantangan, dan cara bertutur kata tidak menyakitkan mitra bicara. Kedua, cara berpakaian dalam acara resmi Samin berupa ikat kepala, celana tokong, dan baju tokong masing-masing berwarna hitam. Akan tetapi, jika tidak dalam acara formal, lazimnya mengenakan pakaian sebagaimana masyarakat non-Samin, tetapi dalam berpakaian

kutipan akta perkawinan, (3) kutipan akta perkawinan sebagaimana ayat (2) masing-masing diberikan kepada suami-isteri, (4) pelaporan sebagaimana ayat (1) bagi penduduk yang beragama Islam dilakukan oleh KUA kecamatan, (5) data hasil pencatatan dari KUA Kecamatan kepada instansi pelaksana dalam waktu paling lambat 10 hari setelah pencatatan perkawinan dilaksanakan. Pasal 35 pencatatan perkawinan (selain di KUA) dilakukan oleh pengadilan yakni perkawinan antarumat yang berbeda agama. Pasal 36 perkawinan yang tak dapat dibuktikan dengan akta perkawinan, pencatatan perkawinan dilakukan setelah adanya penetapan pengadilan. Argumen Samin tak taat UU Perkawinan karena prinsip adanya anak Adam (manusia) karena melalui proses sikep-rabi (persetubuhan) antara Adam dengan Hawa yang tanpa melibatkan pihak lain sebagai saksi atau pencatat (buku) nikah. Hal tersebut diikuti pengikut Samin (Putu Adam) di Kudus dan Pati, Jateng. Keberadaan Adam menduduki alam (jagat whong-whong) masa lalu seorang diri. Maka Yai (Tuhan) menurunkan Adam (Yai Adam) ke dunia agar tak sendirian dan tercipta kehidupan (ora sumung). Adam sikep-rabi (kawin) dengan Hawa (Ibu Hawa) yang disaksikan Yai (Tuhan), bukan manusia. Konsekuensinya perkawinan warga Samin dicerca pemerintah desa dan lingkungannya yang non-Samin. Sebagaimana dialami Santoso, warga Samin Desa Larekrejo, ketika kawin dengan Tianah tahun 1985 diwajibkan pemerintahan desa kawin menyertakan peran negara. Santoso bersikukuh kawin model Samin. Imbasnya dijuluki 'gerpol' gerakan politik, dianggap ora duwe gusti Allah. 
tertentu menjadi pantangan seperti berpeci, berkopyah, berjilbab, dan bercelana panjang. Ketiga, beragama Adam. Konsekuensinya, dalam hal pemulasaraan jenazah, jenazah tidak dikafani dengan kain mori, tidak selalu dimandikan, tidak disalati, tidak diadzani (talqin) ketika di liang lahat, tidak diberi batu nisan, dan tidak diziarahi makamnya. Keempat, perkawinannya tidak melibatkan peran negara (KUA atau Kantor Catatan Sipil) karena dinikahkah oleh orangtuanya secara langsung, tanpa perantara pihak lain, meskipun tidak memiliki surat nikah.

Menurut Purnomo, warga Samin berpegang pada 3 prinsip angger-angger yakni angger-angger pangucap (hukum bicara), anggerangger pertikel (hukum tindak-tanduk), dan angger-angger lakonono (hukum perihal yang perlu dijalankan). Ketiga angger-angger itulah sebagai pengendali secara personal dan sosial. Selain prinsip tersebut, ajaran Samin menyuruh pemeluknya mewujudkan perintah lakonana kanthi sabar trokal (lakukanlah dengan sabar sepenuhnya), sabare dieling-eling (kesabaran untuk dilakukan), trokale dilakoni (kesabaran diwujudkan). Prinsip dan perintah tersebut sebagai kontrol bagi warga Samin ${ }^{18}$.

Warga Samin dalam mewujudkan prinsip dan perintah ajarannya berpegang pada kaidahnya sepisan tan kena wola-wali (sekali tidak boleh berubah) dan bawa laksana (apa yang dikatakan, dijalankan). Hal tersebut menciptakan njaga tata tentreming sepada (menjaga ketenteraman sesama). Warga Samin dalam berinteraksi dengan sesama Samin dan non-Samin menggunakan bahasa Jawa Ngoko. Penggunaan bahasa tersebut sebagai pertanda bahwa komunitas Samin kategori kelas sosial tingkat bawah.

\section{Prinsip Ajaran Samin}

Ajaran Samin dijadikan keyakinan hidup warga Samin berupa dasar ajaran (perintah) dalam bentuk etika, pantangan dasar dalam berinteraksi, berdoa dalam beraktivitas, dan menolak aktivitas yang identik dengan action penjajah Belanda.

18Sucipto Hadi Purnomo, "Mengontrol yang Gung-Binathara", Suara Merdeka, 26 Juni 2011, 20. 


\section{Etika Samin}

Etika Samin tercermin dalam pelaksanaan ajaran Samin yang mengandung prinsip hidup berupa kejujuran, kesetiakawanan, kesederhanaan, kebersamaan, keadilan, dan kerja keras. Prinsip dasar beretika adalah berupa pantangan untuk tidak drengki; memfitnah, srei; serakah, panasten; mudah tersinggung atau membenci sesama, dawen; mendakwa tanpa bukti, kemeren; iri hati (keinginan untuk memiliki barang yang dimiliki orang lain). Nyiyo marang sepodo; berbuat nista terhadap sesama penghuni alam, dan bejok reyot iku dulure, waton menungso tur gelem di ndaku sedulur (menyia-nyiakan orang lain tidak boleh, cacat seperti apapun, asal manusia adalah saudara jika mau dijadikan saudara, dan pantangan berujar norak (saru, tidak sopan). Pantangan Samin versi Purnomo dengan istilah yang menyerupai yakni aja drengki, srei, tukar-padu, dahpen kemeren. ${ }^{19}$

Ajaran tersebut pada dasarnya ajaran agama universal, dan melaksanakan ajaran tersebut sangat ditentukan oleh diri warga Samin, bukan karena simbol menjadi pengikut agama atau kelompok tertentu. Maksudnya, orang Samin berpeluang menjadi warga yang taat dan dapat pula menjadi warga yang tidak taat terhadap ajaran Samin.

\section{Pantangan dalam Berinteraksi}

Interaksi dengan sesama bagi warga Samin memiliki pantangan. Pantangan tersebut terpilah dalam tiga hal yakni ucapan, perbuatan, dan tabiat. Interaksi antarsesama jika tidak memahami karakter dikhawatirkan terjadi ketersinggungan. Untuk mengantisipasinya, ajaran Samin memberi rambu-rambu berinteraksi bagi warganya dalam hal ucapan berupa pantangan yakni nyabdo, pisob-pisoh, sepoto, sumpah, lan nyumpabi awae dewe. Nyabdo; ungkapan yang berisi sumpah-serapah kepada pihak lain karena merasa memiliki daya linuwih (hebat). Pisoh-pisob; ungkapan bernada negatif sebagai ekspresi kekecewaan kepada pihak lain karena merasa dirugikan/dikecewakan. Sepoto; ekspresi lisan yang meneguhkan ketidakbenaran atau mengokohkan kebenaran aktifitas yang telah dilakukannya kepada mitrakomunikasi.

${ }^{19}$ Ibid., 20. 
Sumpah; pernyataan secara lisan dari pengujar kepada pihak lain yang biasanya karena faktor dakwaan. Nyumpahi awae dewe; pernyataan secara lisan dari pengujar kepada dirinya yang biasanya pembelaan karena faktor dakwaan dari pihak lain yang merugikan dirinya ${ }^{20}$. Kelima hal tersebut, dalam ajaran Samin terdapat pesan, tidak akan terjadi jika waspada (waspodo) yakni bertindak yang benar dengan dipikirkan sebelum melangkah (jangkah-jongko) dan waskito (cemerlang dalam memprediksi langkah yang akan dilakukan), diimbangi dengan mengingat aktivitas yang telah dilakukan (ngeleng-ngeleng yeng wes klakon) dan berhati-hati jika akan bertindak (ati-ati yeng durung klakon).

Pantangan berinteraksi bagi warga Samin ketika berhubungan dengan sesama manusia dalam hal perbuatan berupa bedok-colong; menuduh-mencuri, pethil; mengambil barang (barang yang masih menyatu dengan alam atau masih melekat dengan sumber kehidupannya) misalnya: sayur-mayur ketika masih di ladang, jumput; mengambil barang (moditas di pasar) misalnya beras, hewan piaraan, dan kebutuhan hidup lainnya, nemu wae ora keno; menemukan barang menjadi pantangan karena menurut pemahamannya jika ditemukan, si pemilik yang kehilangan tidak akan mendapatkan barang yang hilang.

Adapun prinsip bertabiat Samin meliputi:

(i) Kudu werub te-e dewe; harus memahami barang yang dimilikinya, konsekuensinya tidak memanfaatkan milik orang lain, (ii) Lugu; bila mengadakan perjanjian, transaksi, ataupun kesediaan dengan pihak lain jika sanggup mengatakan ya, jika tidak sanggup atau ragu mengatakan tidak. Jika ragu memberikan jawaban ya atau tidak, mereka berujar cubi mangkeh kinten-kinten pripun, kulo dereng saget janji. (coba nanti kira-kira bagaimana, saya belum bisa menjanjikan). Kecuali jika saat menepati janji menghadapi kendala yang tidak diduga, seperti sakit, (iii) Mligi; taat aturan prinsip Samin, dipegang erat sebagai bukti keseriusan dan ketaatan memegangi ajarannya. Di antara larangan adalah judi, dianggap sebagai pemicu menurunnya semangat kerja dan hubungan seks bebas karena bukan haknya, (iv) Rukun dengan istri, anak, orang tuanya, tetangga, dan dengan siapa saja. Urutan tersebut sebagai skala prioritas, dan (v) larangan beristri lebih dari satu ${ }^{21}$.

${ }^{20}$ Moh. Rosyid, Kodifikasi Ajaran Samin (Yogyakarta: Kepel Press, 2010), 65.

${ }^{21}$ Rosyid, Samin Kudus, 71. 


\section{Tipologi Masyarakat Samin}

Tipologi (golongan manusia menurut corak watak masingmasing dalam berinteraksi dan berkarakter) masyarakat Samin dipilah dalam empat bentuk tipe Samin, meliputi: sangkak, ampeng-ampeng; samiroto, dan sejati atau dlejet22. Pertama, Samin sangkak, jika berinteraksi dengan pihak lain, menjawabnya dengan kirotoboso. Misalnya, teko ngendi, dijawab teko mburi (dari mana?, dijawab dari belakang). Lungo ngendi, dijawab lungo ngarep (dari mana?, dijawab ke depan). Hal ini dilakukan karena bagian dari strategi komunitas Samin (saat penjajahan) yang merahasiakan tempat persembunyian komunitasnya karena hidup menyendiri. Hal ini sebagai bentuk perlawanan terhadap penjajah. Kondisi kini, tipe sangkak tidak dijumpai peneliti karena keberadaan dan aktivitas yang dilakukan warga Samin tidak dirahasiakan. Kedua, Samin ampeng-ampeng; mengaku Samin, perilakunya tidak sebagaimana ajaran Samin atau jika berbicara seperti tipe Samin sangkak, perilakunya tidak seperti Samin sejati. Seperti jika diberi pertanyaan: berapa jumlah anaknya. Dijawab: dua, maknanya laki-laki dan perempuan. Tetapi jika pertanyaannya: berapa hitungannya? Jika mempunyai dua anak, dijawab: dua, satu laki-laki, satu perempuan. Bagi warga Samin tipe ini, merasa dirinya warga Samin, tetapi melanggar prinsip Samin. Ketiga, Samin samiroto, mengaku Samin, tetapi serba bisa, menjadi Samin sebenarnya sekaligus dan dapat juga mengikuti adat non-Samin. Hal ini digambarkan dalam kehidupan warga Samin yang melaksanakan pernikahan dengan dicatatkan di KUA, tetapi perilaku sehari-hari mencerminkan prinsip Samin. Keempat, Samin Sejati atau dlejet, Samin yang berpegang prinsip sebenarnya. Komunitas inilah yang jika dihadapkan dengan peraturan pemerintah kini, masyarakat menganggapnya sebagai komunitas pembangkang karena ajaran leluhurnya dalam konteks masa penjajah, masih tetap dilaksanakan apa adanya hingga kini, seperti tidak sekolah formal dan tidak memiliki KTP. Karakter tersebut merupakan bentuk perlawanan tidak kasat mata terhadap Belanda. Realitanya karakter tersebut tidak selalu bersamaan, maksudnya boleh jadi seorang Samin

22Rosyid, Kodifikasi Ajaran, 18. 
melaksanakan ketiganya atau salah satunya. Hal itu ditentukan pola pikir dan respons ketika bertemu dengan orang non-Samin, dan faktor tidak terduga lainnya. Pola pikir tersebut adalah imbas pendidikan formal yang ditempuhnya, terbuka menerima budaya di luar Samin dan menerima modernitas, ${ }^{23}$ meski mereka memiliki strategi dalam mempertahankan jati diri. ${ }^{24}$

\section{Keberagamaan Masyarakat Samin}

Paparan di bawah ini mengulas munculnya agama bagi warga Samin dan polemik keberagamaan Samin.

\section{Agama bagi warga Samin}

Pramugi Prawiro Wijoyo menyebutkan bahwa:

Sekitar tahun 1890, ketika Ki Samin berumur 31 tahun, ia menyebarkan ajaran 'sikep' di desa-desa dengan cara masuk-keluar desa di lingkungan hutan. Ia juga menimba ilmu dan bertapabrata di hutan dan tapa ngrame di desa-desa. Tapa tersebut bertujuan mendekatkan diri pada Hyang Kuasa, sehingga mendapatkan wahyu dan bimbingan dari gaib (Yal) atau Hyang Kuasa. Wahyu berisi perintah menata umat manusia agar selalu berbuat baik dengan sesamanya. Materi ajarannya berupa sifat

23Santoso, tokoh Samin Desa Larekrejo, Undaan, Kudus diundang Institut Pertanian Bogor (IPB) dalam forum temu tani nasional dan sarasehan petani pada Dies Natalis IPB ke-32 4 s.d 7 September 1995 di Bogor. Ia menjadi Ketua RW, aktif dalam Kelompok Bantuan Desa bidang pertanian di Desa Larekrejo. Begitu pula Wargono, tokoh Samin Dukuh Kaliyoso, Desa Karangrowo, Undaan, Kudus, semasa Bondan Gunawan menjadi staf Presiden Abdurrahman Wahid (Gus Dur), singgah di istana negara, Jakarta. Mendapat undangan pelantikan Bupati Kudus, Musthofa karena tim sukses Pilbup bagi warga Samin di Kudus. Tak bedanya warga Samin Desa Sambongrejo, Sambong, Blora, Pramugi Prawiro Wijoyo, peraih lomba kelompencapir Jawa Tengah, Juara I tingkat nasional lomba perintis lingkungan hidup/kalpataru, dan penerima satya lencana bidang lingkungan hidup dari Presiden RI tahun 2009. Suara Merdeka, 24 November 2009, 1.

${ }^{24}$ Pertama, mentradisikan ajaran sejak kecil melalui tauladan orangtua dan tokoh (botoh) berkedudukan (1) guru kehidupan. Guru dari kata 'gu': gunem dan 'ru': kawruh. Jika memberi ujaran bermakna dalam kehidupan, (2) sebagai orang tua, dan (3) tauladan hidup bagi generasi Samin yang mampu mentransfer ajaran tersebut pada generasinya. Kedua, keteladanan; dengan tauladan dari orangtua dan tokohnya memunculkan kesan bahwa doktrin yang diberikan tak sebatas bahan pembicaraan. Ketiga, hidup dalam satu kawasan. Keempat, pernikahan dengan Sesama Samin. 
demen, becik, rukun, seger, waras dan menjauhkan diri dari sifat jrenki, srei, panasten, dahpen, kemeren. Pada suatu hari, Ki Samin mendapat petunjuk dari Yai agar beliau menimba ilmu (ngenger) pada Modin Kamolan yakni seorang yang baik, arif, dan bijaksana serta berilmu tinggi. Akhirnya, Ki Samin menjadi suami dari puteri kedua Modin Kamolan. Selanjutnya, Ki Samin menyebarkan 'ilmu'-nya di Desa Ploso Kediren, Kecamatan Randublatung, Blora. Ajaran sikep dikembangkan Ki Samin hingga di wilayah Bapangan, Tanduran, Kemantren, Gondel, Medalem, Blimbing, Sambong, Kabupaten Blora. Penyebarannya meluas di wilayah Rembang, Pati, dan Kudus, Jawa Tengah bahkan di wilayah Kabupaten Bojonegoro, Ngawi, dan Madiun, Jawa .Timur ${ }^{25}$. Materi ajaran berupa (1) menata hidup dan penghidupan pada masyarakat tentang tataning sikep rabi, ilmu pendunungan, dan sejatining urip lan urip kang sejati. Hal tersebut diharapkan manusia hidup di dunia mendapatkan kasampurnaning urip. (2) Wong urip kudu ngerti uripe, sebab urip mung sepisan kanggo selawase. (3) manusia harus selalu berbuat baik kepada sesamanya, lingkungan dan alam semesta. (4) wong nandur bakal ngunduh, wong kang gawe bakale nganggo, wong kang utang bakale nyaur. Mula aja tumindak jrengki, srei, panasten, dahpen lan kemeren marang sepadane urip. Amarga wong urip kabeh mau mung sak derma nglakoni, wong urip iku ana kang nguripake, mula kudu sabar lan narima ${ }^{26}$.

Komunitas Samin dalam beragama berprinsip aku wong Jowo, agamaku njowo (Aku orang Jawa, agamaku njowo yakni Adam). Kata Adam bagi warga Samin diberi makna kawitan atau pisanan yakni orang yang pertama kali menghuni alam dunia. Proses transformasi ajarannya sabdo tampo rapal (ajaran tidak tertulis) dengan dasar sahadat, panetep, lan panoto agomo. Agama Adam bagi masyarakat Samin diakui sebagai agama yang dibawa sejak lahir. Esensi dasarnya adalah sebagai perwujudan "ucapan" (tandeke neng pengucap, opo wae thukule soko pengucap) dan diwujudkan dengan akivitas yang baik. agama iku gaman, adam pengucape, man gaman lanang (agama Adam merupakan senjata hidup). Prinsip beragama bagi pemeluk agama Adam adalah wonge Adam (mengakui bahwa orang pertama adalah Adam), lakune Adam (berperilaku yang mewujudkan prinsip dan pantangan dalam ajaran Samin), pengucape Adam (jika sanggup dalam perjanjian dikatakan sanggup, jika tak sanggup dinyatakan tak sanggup), dan agomone Adam (agomo minongko gaman utowo alat kanggo urip

25Pramugi Prawiro Wijoyo, Giyare Kaki Samin Surosentiko Bab Lakon 'Sikep’ Winongko Paugerane Urip Kang Demunung, (ttp: tp, 2011), 2.

26Ibid., 3. 
yang diwujudkan dalam berperilaku sesuai prinsip dan menjauhi pantangan dalam ajaran Samin).

Ajaran Samin menandaskan bahwa sejatine agama yaiku ugeman/ageman urip, ${ }^{27}$ esensi agama adalah pegangan hidup yang tercermin dalam prinsip ajaran dan pantangan. Kenyamanan batin merupakan esensi dasar keyakinan yang disebut agama.

\section{Polemik Keberagamaan Samin}

Agama komunitas Samin diragukan oleh sebagian publik karena tidak tertuang dalam perundangan. Begitu pula nama agama 'Adam' masih asing bagi publik. Dengan demikian, muncul pertanyaan, benarkah Samin ateis? Jika jawabannya Samin bukan ateis, dalihnya, ajaran Samin memiliki Sang Hyang Wenang (Tuhan atau Yai), berpegang pada kitab Jamus Kalimasada berbahasa Jawa berbentuk puisi tradisional (tembang macapat) dan prosa (gancaran), meskipun substansi kitab tersebut diwariskan secara lisan pada generasinya karena kitab itu diduga musnah ketika Ki Samin ditahan Belanda. Keraguan sebagian publik terhadap agama yang dipeluk masyarakat Samin, berimbas terhadap keraguan keberagamaannya, maksudnya aktivitas keagamaan yang dilakukan masyarakat Samin dianggap publik sebagai tradisi universal, bukan perilaku beragama.

Di sisi lain, ajaran agama Samin (Adam) tidak memiliki konsep yang sama dengan ajaran agama yang dipeluk mayoritas pemeluk non-Samin (Islam) di antaranya konsep Samin tentang kehidupan pasca-kematian. Orang yang telah mati, arwahnya akan menitis pada generasinya, bila perilakunya semasa hidup baik, kebaikannya menempel pada diri generasinya, sehingga makam tidak mendapat perhatian, tak sebagaimana konsep makam menurut perspektif masyarakat Jawa.

Tjipto Mangunkusumo, terinspirasi laporan J. E Jaspers tahun 1917 tentang gerakan petani Het Saminisme, Rapport uitgebracht aan de Vereeniging Insulinde, mendedahkan bahwa

${ }^{27}$ Kata ageman atau pakaian secara harfiyah memiliki tiga makna yakni menjaga kesehatan, menutup aurat, dan memperindah penampilan. Secara substansial, ageman bermakna keyakinan dan tradisi yang membuat seseorang berharga serta pantas dihargai, merasa percaya diri, dan nyaman bersesama. Komarudin Hidayat, “Agama itu Ageman”, Kompas, 22 Oktober 2011, 6. 
saminisme mempunyai kemiripan dengan sekte agama pembangkang di zaman Tsar Rusia sebelum revolusi Boltsewik 1914-1917. Sekte itu tidak memercayai adanya Tuhan, malaikat, dan surga, tetapi lebih memercayai yang 'nyata'28. Realitasnya, pendapat Mangunkusumo tersebut bertolak belakang dengan pegangan hidup dalam agama Adam yakni memercayai adanya Tuhan (Yai) dan memercayai hal-hal yang abstrak, seperti jin dan sejenisnya. Menurut Suripan, era politik bagi Samin telah berlalu, Saminisme tidak harus dipahami sebagai ideologi perlawanan kaum tani, melainkan sebagai ajaran kebatinan ${ }^{29}$. Berpijak pada UU Nomor 1/PNPS/1965 ${ }^{30}$ ditandaskan bahwa hanya 6 agama yang dieksplisitkan dalam perundangan, meskipun negara tak berposisi sebagai lembaga yang 'mengakui' agama, tetapi fasilitator bagi pemeluk agama. Konsekuensinya setiap agama yang dipeluk warga negara tetap dilindungi negara ${ }^{31}$.

\section{Esensi Agama Adam}

Para sosiolog agama mengklasifikasikan agama menjadi dua, agama kebudayaan dan agama samawi. Agama kebudayaan (cultural religious, agama tabi'i, atau agama ardi) yaitu agama yang bukan berasal dari Tuhan dalam proses pewahyuan, tetapi hasil proses antropologis yang terbentuk dari adat-istiadat dan melembaga dalam bentuk agama formal. Formalisasi agama diukur adanya bentuk dan rasa beragama bagi individu dalam

${ }^{28}$ Norkhoiron, "Dari Buku ke Buku Sambung Menyambung Menjadi 'Samin", Majalah Kebudayaan, Desantara: Jakarta. edisi 6/tahun II/2002, 4.

${ }^{29}$ Ibid., 9.

30Penjelasan Pasal 1 bahwa agama yang dipeluk penduduk di Indonesia ialah Islam, Kristen, Katolik, Hindu, Buddha dan Khong Huchu (Confusius). Keenamnya dipeluk hampir seluruh penduduk Indonesia kecuali mereka mendapat jaminan sebagaimana Pasal 29 (2) UUD 1945 juga perlindungan. Agar pemeluk agama kokoh, pemerintah memfasilitasinya dibentuknya Depag yang menjadi penyelenggara ibadah agama (haji), perkawinan, menangani bidang pendidikan agama dan pendidikan keagamaan.

${ }^{31}$ Agama lain, misalnya Yahudi, Zarasustra, Shinto, Taoism tidak dilarang di Indonesia, tetapi mendapat jaminan penuh, sebagaimana tertuang dalam UUD 1945 Pasal 29 (2). Mereka dibiarkan adanya, asal tidak melanggar ketentuan dalam peraturan ini atau perundangan lain (Penjelasan UU Nomor 1/PNPS/1965). 
komunitasnya. Agama kebudayaan memiliki ciri khas yakni adanya Tuhan (dengan istilah khas masing-masing), adanya sumber ajaran, adanya komunitas, adanya tokoh sebagai pemimpin, meskipun tidak semua memiliki tempat suci agama. Sebagaimana agama Adam yang dipeluk warga Samin tidak memiliki tempat suci beribadah yang bersifat kolektif, tetapi hanya untuk ibadah individual yang disebut sanggar pamujan. Terbatasnya negara memfasilitasi agama kebudayaan tersebut, dampaknya eksistensi aliran kepercayaan berada di bawah naungan Kementerian Pendidikan dan Kebudayaan, Subdit aliran kepercayaan, bukan di bawah naungan Kementerian Agama. Di sisi lain, tak terbatasnya jumlah agama lokal yang tidak selalu terekspos atau tidak ingin 'menampakkan' diri di hadapan publik sebagai penyebab sulitnya mendata jumlah pemeluknya bagi pemerintah. Pemeluknya puas dengan kejatidiriannya yang ujung pangkalnya terletak pada etika sosial yang adiluhung. Hal ini diwujudkan dalam berinteraksi sosial maupun interaksi vertikal. Kesalehan individu, sosial, dan vertikal adalah potensi diri yang tidak selalu sama antarindividu pemeluk agama. Agama samawi atau agama wahyu (revealed religion) merupakan agama yang dipercaya oleh pemeluknya sebagai hasil dari wahyu Tuhan melalui malaikat-Nya kepada rasul-Nya (full fledged), memiliki kitab suci, dan memiliki umat (pengikut) ${ }^{32}$.

32Para antropolog dan sosiolog agama mengklasifikasikan agama terdiri spiritualisme dan materialisme. Spiritualisme adalah agama penyembah dzat yang gaib dan tidak berbentuk (nonkonkret). Spiritualisme terpilah menjadi agama ketuhanan dan agama penyembah roh. Agama ketuhanan (theistic religion) yaitu agama yang penganutnya menyembah Tuhan (theos). Penyembahan itu menganggap keberadaan Tuhan Yang Maha Esa (monoteis) dan keberadaan Tuhan dianggap banyak jumlahnya (politeis). Agama penyembah roh adalah kepercayaan orang primitif kepada nenek moyang, roh pemimpin, roh para pahlawan yang telah meninggal, dan sebagainya. Agama penyembah roh terdiri animisme dan praanimisme (dinamisme). Kelompok materialisme beranggapan agama mendasarkan kepercayaan terhadap Tuhan yang dilambangkan dalam wujud materi (benda) seperti patung, berhala, binatang atau lainnya. Sumber agama dalam perspektif ilmuwan (khususnya sosiologi agama) terpilah menjadi dua yakni agama yang bersumber dari langit (vertikal, abrahamik) dan bersumber dari budaya manusia (agama budaya, wadi atau horisontal). Kedua pilahan tersebut 
Esensi dasar manusia memeluk agama menurut penulis adalah untuk konsumsi batinnya, sehingga ketenteraman, kesalehan, dan kepedulian terhadap lingkungannya merupakan perwujudan keberagamaan individu. Dengan klasifikasi agama tersebut muncul sekte yakni suatu kelompok keagamaan yang memisahkan diri dari suatu agama induk, biasanya sebagai protes terhadap agama induknya dalam hal doktrin maupun kepemimpinan. Adapun ciri sekte adalah adanya pemimpin karismatik yang melakukan penafsiran baru terhadap ajaran yang telah dianutnya, biasanya keanggotaan sekte terbatas dan bersifat eksklusif dalam kaidah beragama.

Kata 'Adam' menyangkut hal pengucap (ungkapan), laku (perilaku), dan penganggo (pakaian). Pengucap bermakna jika berbicara tidak bohong dan dapat dipercaya. Sedangkan laku diwujudkan dalam perilakunya tidak melanggar prinsip Samin. Adapun penganggo adalah tata cara berpakaian sesuai dengan ajarannya. Penamaan agama Adam bagi warga Samin, diilhami dari pemahamannya bahwa orang pertama kali yang menghuni alam raya ini adalah Adam, disusul ibu Howo. Kata "agama" bukan berarti tradisi tersebut menjadi agama yang terpublikasikan, namun lebih bermakna “ugeman' atau pegangan hidup. Jika sebagai agama, tentunya melalui birokrasi

memiliki perbedaan mendasar. Agama langit prinsip dasarnya bertuhan, berkitab suci, dan bernabi. Adapun agama bumi pun bertuhan, tetapi (tidak selalu) berkitab suci, dan tidak bernabi. Pilahan agama tersebut (vertikal dan horisontal) sifatnya sepihak (oleh dan untuk kalangan tertentu ternafikan). Dapat pula dinyatakan bahwa esensi dasar agama 'langit' adalah keesaan dan terciptanya rahmatan li al-ālamin. Agama Samawi berciri (1) ada kepercayaan terhadap yang gaib, Kudus, Maha Agung dan Pencipta alam semesta (Tuhan), (2) melakukan hubungan dengan hal-hal tersebut di atas, dengan berbagai cara, seperti upacara, ritual, pemujaan, pengabdian dan doa, (3) ada ajaran (doktrin) yang dijalankan oleh penganutnya, dan (4) dalam agama Islam, ajaran tersebut diturunkan melalui perantara (Rasul) dan bukan langsung kepada manusia. Kebenaran dan pengetahuan yang bersumber dari agama menggunakan metode thetis deduktif. Thetis maksudnya bertitik tolak dari aksioma-aksioma atau dalil-dalil agama yang tidak dapat ditolak kebenarannya, sementara deduktif berarti bahwa kebenaran tersebut disusun dari prinsip-prinsip yang berlaku umum menuju hal-hal yang khusus. Dadang Kahmad, Metode Penelitian Agama Perspektif Ilmu Perbandingan Agama, (Bandung: Pustaka Setia, 2000). 
pemerintahan yakni tertuang dalam perundangan dan memenuhi syarat sebagai agama. Disebut agama, versi sosiolog agama, jika memenuhi syarat sebagai agama seperti memiliki kitab suci, mempunyai nabi sebagai pembawa risalah, dan ajarannya dikaji terbuka untuk publik ${ }^{33}$. Di sisi lain, ugeman Adam bersifat untuk diri pribadi dan kelompoknya, tidak untuk disosialisasikan pada publik. Ugeman tersebut bermuatan ajaran etika hidup menjadi kepercayaan yang dipertahankan dalam pendidikan nonformal (keluarga) dengan model tuturan/tradisi lisan (oral tradition) dan tauladan oleh figur (orangtua dan tokohnya).

Keberadaan Adam dianggap orang pertama di dunia agar dunia sejahtera (ndonyo rejo). Lahirnya Adam dan ibu Howo karena sabdo tunggal Yai sebagai penguasa tunggal. Adanya Yai karena adanya Adam (Ono iro ono ingsun, wujud iro wujud ingsun. Aku yo kuwe, kuwe yo Aku, wes nyawiji). Yai bermakna yeng ngayahi samubarang kebutubane putu, putu duwe kewajiban, putu njaluke karo Yai kanti ngeningke cipto, roso, lan karso kang supoyo biso kasembadan sejo lan karep kanti neng, neng, lan nep. Yai bermakna dzat yang memenuhi hajat hidup makhluk, makhluk pun memiliki kewajiban. Jika makhluk memohon hanya kepada-Nya dengan mengheningkan cipta (semedi).

Pengakuan masyarakat Samin bahwa dirinya beragama Adam dengan prinsip etika adiluhung berpegang pada kitab Jamus Kalimasada ${ }^{34}$. Esensi agama Adam bagi masyarakat Samin adalah jika pemeluknya mampu melaksanakan prinsip ajaran dan meninggalkan pantangan kesaminan, sekaligus berpatokan pada garis besar 'syariatnya' yakni tidak berbohong, tidak menyakiti hati lingkungannya (manusia, hewan, dan tumbuhan, sehingga dalam menyembelih hewan mereka memiliki ritme tersendiri),

${ }^{33}$ Ajaran 'dalam' Samin hanya diperuntukkan bagi pemeluk agama Adam karena proses transformasi ajaran agamanya melalui tahap nyintreni (pentahbisan). Berpegang pada prinsip yeng jero ora keno metu, yeng jobo keno mlebu (yang memeluk agama Adam tidak diperkenankan meninggalkan ajaran. Warga non-Samin diperkenankan menjadi Samin). Proses perpindahan agama bersifat individu (sol salen toto).

${ }^{34} \mathrm{Kitab}$ tersebut berbahasa Jawa berbentuk puisi tradisional (tembang macapat) dan prosa (gancaran), meskipun substansi kitab tersebut diwariskan secara lisan pada generasinya karena kitab itu musnah, ada dugaan musnahnya kitab ketika Ki Samin ditahan Belanda. 
tidak beristeri lebih dari satu (dianggap sumber konflik), berpantangan menemukan barang orang lain (jika ditemukan, pemilik yang kehilangan tak akan mendapatkan barang yang hilang), dan tidak mencuri. Ibadahnya (semedi) dengan memohon dan memuji pada Tuhan/Yang, berpuasa Suro, berpuasa pada hari kelahiran. Keberadaan Samin versi kolonial Belanda (semula) dianggap ajaran kebatinan, embrio munculnya agama baru. Menurut Soerjanto semula gerakan ritual mistis ${ }^{35}$. Dugaan tersebut mendekati benar karena Samin memiliki agama sendiri (agama Adam), tidak sebagaimana agama yang dieksplisitkan dalam perundangan ${ }^{36}$. Tumbuhnya ajaran Samin berpijak dari sumber ajarannya yang tertuang dalam kitab sucinya, antara lain Serat Uri-uri Pambudi, Serat Jamuskalimasada. Kitab itu berisi tulisan Samin yang mengajarkan ajaran kebatinan, sedangkan menurut Suripan, ajaran kebatinan Samin terpenting adalah manunggaling kawula Gusti atau sangkan paraning dumadi. Serat Punjer Kawitan karya Samin Surosentiko (1859-1914) ditemukan di Desa Tapelan, Blora ${ }^{37}$. Kini kitab tersebut tidak didapatkan penulis.

Memiliki aliran kepercayaan bagi seseorang, pada dasarnya adalah wilayah diri, bersifat pribadi, dan membutuhkan kenyamanan diri dalam berinteraksi sosial, dengan catatan kepercayaan tersebut tidak mengganggu kenyamanan pemeluk agama atau kepercayaan pihak lain. Hal tersebut tercipta jika tak ada kesamaan nama (kepercayaan) dan tak mengusung substansi ajaran agama/kepercayaan lain dengan nama yang telah ada. Meskipun dalih utama bahwa berkepercayaan adalah hak dan

${ }^{35}$ Sastroatmodjo, Masyarakat Samin, 51.

${ }^{36}$ Keenam agama tersebut yang 'tidak direspon' rezim Orba, Konghucu karena imbas politik. Era pasca-Orba, era reformasi, keberadaan Konghucu mendapat posisi proporsional, diterbitkannya surat Menag No: MA/12/2006 menegaskan masih diberlakukannya UU No. 1/PNPS/1965 dan diperkuat surat edaran Mendagri No. 470/336/SJ tanggal 24/2/2006 tentang pelayanan adminduk bahwa penganut agama Konghucu, dalam poin (2) disebutkan kepala daerah diminta untuk memberikan pelayanan administrasi kependudukan kepada penganut agama Konghucu dengan menambah keterangan agama Konghucu pada dokumen administrasi kependudukan yang digunakan.

${ }^{37}$ Norkhoiron, "Dari Buku, 9. 
kebutuhan batin bagi individu. Dengan demikian, keberadaan aliran kepercayaan tidak selalu mudah terdeteksi oleh pemerintah karena keberadaannya yang bersifat pribadi, tidak (selalu) ingin publikasi, dan berkelompok dalam jumlah terbatas. Adapun ciri umum penghayatan adalah (i) menghayati kesadaran hidup dan mengendalikan motivasi hidup berdasarkan Ketuhanan Yang Maha Esa yang bersumber dari Tuhan, (ii) penghayatan memberi kemampuan manusia untuk mengetahui (cipta), menimbang (rasa), dan mengerti (cipta rasa) yang dikelola oleh hati nurani dan budi luhur, dan (iii) penghayatan menciptakan sistem pengawasan yang bulat berupa: sadar hidup (eling), mawas diri (serpih hidup utuh/pandum), mawas sesama (tepo saliro, tenggang rasa), mawas alam lingkungan (memayu hayuning bawana), mawas luhur (guru sejati, tertampung dalam tuntutan hidup) ${ }^{38}$. Kajian tentang esensi agama Adam dalam paparan ini meliputi peribadatan, ajaran tertinggi Samin, eksisnya agama Adam, dan aktivitas keberagamaan pemeluk agama Adam.

\section{Peribadatan Pemeluk Agama Adam}

Peribadatannya melaksanakan syariat agamanya yakni Adam yang berbeda dengan syariat yang dipeluk mayoritas masyarakat di lingkungan Samin (Islam), seperti (1) pemulasaraan jenazah yakni jenazah tidak selalu dimandikan dan tidak disalati, meskipun dikafani sebagaimana agama mayoritas di lingkungannya (Islam), (2) penyembelihan hewan berpola sendiri, terutama dalam hal doa penyembelihan, (3) mentradisikan puasa suro dan puasa hari kelahiran. Dalam hal puasa ini, tergantung kesalehan diri warga Samin dalam menjalankan ajaran agamanya. Ibadah yang dilakukan warga Samin dalam bentuk berdoa dalam semedi, topo, meditasi, puasa, dan mendistribusikan sebagian harta pasca-panen.

\section{Doa Warga Samin}

Aktivitas warga Samin dikategorikan aktivitas kumulatif jika dilaksanakan semua pengaku ajaran Samin, sedangkan aktivitas nonkumulatif adalah aktivitas peribadatan yang tidak

\footnotetext{
${ }^{38}$ Ensik.lopedi Nasional Indonesia, 2004:400.
} 
dilaksanakan semua pengaku ajaran Samin (bersifat individu). Komunitas Samin yang saleh, dalam beraktivitas biasanya diawali berdoa. Doa tersebut terdapat perbedaan ungkapan karena perbedaan tokoh yang memberi petuah. Seperti doa penyembelihan hewan. Yang bumi, aji aku jaman. Jamanku....(menyebutkan nama diri) sandang-pangan tukule bumi. Ada pula yang memanjatkan doa: mragat retak-retik sreh gajeh, meskipun warga Samin lainnya, tidak memperkenankan menyampaikan ajaran 'dalam' kesaminan, seperti doa menyembelih hewan (mbenggang) dengan ungkapan: kune ngerti utowo ora ngerti, podo wae (Kamu tahu atau tidak tahu ajaran agama Samin, sama saja karena bukan pengikut ajaran Samin). Etika dan tata cara berdoanya dengan ngenengno cipto, roso, lan karso kang supoyo biso kasembadan sejo lan karep kanti neng (ngeningke cipto), ne'ng (kudune meneng), lan nep (ngenepno roso yoiku onone siro utowo ingsun, wujud iro wujud ingsun) kalayan rungu tan rinungu, ono roso tan rinoso, ono gondo tan ginondo. Aktivitas doa tersebut kategori aktivitas kumulatif atau nonkumulatif.

Bentuk peribadatan warga Samin berupa berdoa ketika semedi dengan prinsip nindakno neng-neng meneng, nenuwun marang yeng momong jiwo rogo, bakale keturutan pengangenane (melaksanakan konsentrasi dengan diam (semedi), memohon pada pemelihara jiwa raga, agar harapannya terpenuhi) dan wong urip kudu percoyo, ora keno mujo kayu-watu, sing dipujo awae dewe (orang hidup harus percaya adanya Yai (Tuhan), tidak boleh memuja kayu-batu, yang dipuja dirinya (awak dewe) terdiri dari kesatuan (manunggaling kawulo marang gusti) dan adanya manusia karena adanya Tuhan. Kata 'Yai' bermakna kabeh yeng ngayahi (semua kebutuhan hidup manusia dicukupi Tuhan) dan keberadaan manusia sebagai hamba (putu Adam). Permohonan masyarakat Samin kepada Tuhan menyertakan peran lingkungannya yang Samin dan nonSamin, misalnya, kematian atau sunatan (ngislamke/brabikke/khitanan) berbentuk brokohan. Hal itu bertujuan untuk mendoakan agar yang masih hidup selamat dan yang telah mati tercapai angan-angan berupa menjadi asal manusia yang menitis pada anak cucu menjadi orang yang baik. Doa brokohan ditujukan kepada (i) anak yang disunat, (ii) sedulur tua dan muda (saudara tua yang lahir bersama kakang kawah adi 
ari-ari [plasenta]), (iii) dulur empat (indra pencium, perasa, penglihat, dan pendengaran/penggondo, pengroso, peningal, lan pengrungu) dan 5 wujud (bayi), (iv) danyang (dirahasiakan oleh narasumber), dan (v) meroi dino (mengetahui hari) dengan dalih ketika alam dunia belum terhuni (whong-whong), hari dibagi dua, bengi (malam) dan rino (siang), sehingga hari ada satu. Adapun penamaan hari (Sabtu, dan seterusnya) disebut aran. Semua hari, bagi komunitas Samin, dianggap baik karena sebelum manusia lahir telah ada hari.

Semedi merupakan bagian dari jalan menuju ketenangan dan kebahagiaan hidup manusia. Semedi sebagai proses introspeksi diri (eling) pada diri dan perilakunya. Semedi atau Samadi ${ }^{39}$ merupakan istilah khas dalam agama Hindu sebagai cara kebaktian kepada Hyang Widhi, Tuhan Yang Maha Esa dengan memusatkan pikiran dan jiwa. Dalam falsafah Hindu, semadi pada tahap kedelapan pelaksanaan yoga, merupakan situasi batin yang sunyi dan sebagai sumpah suci, pasrah diri sepenuhnya dalam berkontemplasi mengatasi segala kesukaran hidup. Untuk menuju konsentrasi, harus melalui tiga tingkatan yakni konsentrasi persiapan (parikamma-samadhi), konsentrasi tetangga (upacara-samadhi), dan konsentrasi penuh (appana-samadhi) ${ }^{40}$. Praktik semedi dapat dilakukan dengan nyepi lan ngrameni. Nyepi (meninggalkan keramaian) biasanya dilakukan di hutan, gua,

${ }^{39}$ Semadi dari bahasa Sanskerta, dari kata 'samadi' artinya maju ke depan untuk mencapai kesempurnaan, memperoleh keyakinan, dan mengatasi kesukaran dalam kehidupan. Menurut Sastroamidjoyo (1964) kata semedisemadi berasal dari bahasa Sansekerta, samadhi, artinya minat yang bersifat keagamaan atau pemusatan perhatian secara khidmat. Adapun rambu-rambu semedi antara lain tata, titi, ngati-ati, langgeng, tlaten, atul. Tata adalah persiapan dengan membersihkan tempat dan ketepatan waktu secara rutin, sedangkan titi adalah memusatkan pikiran terhadap hal yang dituju (kang ka-esthi) hingga mencapai tahapan kahenengan. Adapun ngati-ati adalah kondisi tidak tertekan dan dalam kondisi tenang-tenteram, dan langgeng adalah menjaga kontinuitas, terus-menerus (netepi). Menurut Martosoepadmo (1958) semedi bermakna nyuwung (sunyi, kosong, tiada penghuni) atau nglowong yang bermakna tidak berbuat apa-apa secara lahir atau batin disebut juga alam sunyaruri yakni keadaan di masa lampau, sejak lama atau kehampaan yakni masa sebelum alam dunia ada beserta isinya. Wawan Susetya, Hawa Nafsu Orang Jawa, (Yogyakarta: Narasi, 2007), 23-6.

${ }^{40}$ Ensiklopedi Nasional Indonesia, 2004: 495. 
gunung, ruang tertutup, dan sebagainya. Semedi dilakukan dengan wirid (zikir) dan menyendiri di tempat sepi (uzlab). Dalam proses wirid, ada kalanya lupa (ghofilin) dengan Tuhannya, ingat kepada Tuhan (hanya) ketika wirid, dan wirid atau tidak wirid tetap ingat Tuhannya. Adapun yang dimaksud ngrameni (tidak meninggalkan keramaian) adalah semedi yang dilakukan di rumah atau saat wirid tetap bergaul dengan masyarakat. Semedi mengharapkan keheningan dan memunculkan rasa ayem-tenterem karena hatinya lerem dan menep, tidak menjadi bungah ngetpiyah (senang berlebihan atau kegembiraan yang meluap). Dengan hening diharapkan tercipta heneng-hening-heling-hawas atau henengbenong (ning-nong).

Menurut Martosoepadmo (1958) melakukan semedi melalui tahap keheningan atau lerem (mengendap) identik dengan memasuki alam kasunyatan melalui tiga fase (ora weruh, ngaku weruh, dan nyata werub). Fase ora werub (belum diketahui) dalam bahasa Sansekerta (a-gama) yakni ilmu pengetahuan yang belum atau tidak disadari kebenarannya. Fase ini dapat dipercayai atau tidak dipercayai. Fase ngaku weruh adalah fase seseorang yang kadang terlintas terbuka dinding hati (bijab), sehingga ia berani mengklaim mengetahui kebenaran (ngaku werub) dalam bahasa Sansekerta disebut ammanah. Artinya menyatakan tahu kebenaran (ngaku weruh) meskipun belum nyata sepenuhnya (sejati). Adapun fase nyata werub adalah jika seseorang benar-benar mengusahakan dengan sungguh-sungguh dan konkrit sehingga menjadi tahu dengan sebenarnya (nyata werub) dalam bahasa Sansekerta disebut pratyaksa. Ketiga fase tersebut oleh Wawan diidentikkan dengan ilmu yaqin, pengenalan/keyakinan berdasarkan ilmu, 'ainul yaqin, pengenalan/keyakinan berdasarkan penglihatan mata hati, dan baqqul yakin, pengenalan/keyakinan sebenarnya (sejati) dan tidak terbantahkan ${ }^{41}$.

Bagi pelaku semedi termasuk warga Samin (biasanya) dihadapkan perasaan dan bayangan menyenangkan (nengsemake), menakutkan (nggegirisi), membingungkan, mengkhawatirkan, kasihan terhadap dirinya sendiri dan larut di dalamnya. Meskipun hal tersebut sebagai penghalang (bijab, aling-aling), solusinya meneruskan rasa ingat kepada Tuhan, mata setengah terpejam

\footnotetext{
${ }^{41}$ Susetya, Hawa Nafsu, 32.
} 
(liyep) dan setengah sadar-setengah tidak sadar (layap) dan lupa sebentar (luyup). Jika hal tersebut mencapai tahap liyep-layaping ngaluyut kemudian ingat (eling) sebagai pertanda pramana menjadi menyatu (nunggil raos) ${ }^{42}$.

Keberhasilan semedi menurut Soedjonoredjo berupa: Pertama, terangnya penglihatan hati, terangnya rasa (kandhasing raos) atau mendalamnya rasa karena terbiasa dengan olah rasa, dan terangnya pengertian batin (pengertos batos) dengan indikator (tanda) pramana, yakni bening penglihatannya dan rasa-pangrasa dan pengertian batin, sehingga menjadi tidak keliru, tidak salah (tan samar). Kedua, dengan terangnya penglihatan menjadi terealisasi (anjumenengaken) dalam kehidupan menjadi khusuk dan benar-benar tenang (makrifat) yakni mengetahui (merubi) kemudian disimpan dalam lubuk dan terpatri. Ketiga, yoga (concentration), hilang (muksa) atau kelepasan (delivence), nirwana (nirbana) dan kewalya (sewalda) berarti suci atau murni. Lebih konkritnya menjadi insan yang murah hati, akhlak yang mulya, keperwiraan (chivalrousry), kemegahan (glory) yang digenggamnya ${ }^{43}$.

Pelaksanaan semedi dalam ajaran Samin pada prakteknya melakukan neng yakni ngeningno cipta (mengheningkan cipta), ne'ng yakni kudune meneng (harus diam), dan nep maksudnya ngenepke kerso dengan memahami prinsip onone siro onone ingsun, wujud iro wujud ingsun (karena keberadaan Adam maka manusia menjadi ada, wujud Adam adalah mewujudkan adanya manusia). Semedi tersebut dengan prinsip ono rungu tan rinungu (ada suara tidak dihiraukan), ono roso tan rinoso (ada rasa tetapi tidak dirasa), dan ono gondo tan ginondo (ada bau tidak dicium/tidak dirasakan).

Selain Semedi juga melakukan topo yakni lelaku untuk mendapatkan harapan hidup dengan semedi/meditasi dalam waktu relatif lama. Biasanya dilakukan di tempat khas/tertentu (pertapan) yang memiliki 'magnet' gaib. Menurut Wawan, topo (topobroto) sebagai bentuk panembah untuk mendekatkan diri kepada Gusti Kang Akarya Jagad berbentuk (i) topo ngalong; dengan menggantung terbalik, kedua kaki diikat pada dahan pohon, (ii) topo ngluwat, dilaksanakan di makam seseorang dalam waktu

\footnotetext{
${ }^{42}$ Ibid., 54.

${ }^{43}$ Ibid., 52.
} 
tertentu, (iii) topo mbisu; menahan diri dari bicara, (iv) topo bolot, tidak mandi dan tidak membersihkan diri dalam jangka waktu tertentu, (v) topo ngidang; menjauhi keramaian, hidup di hutan dan makan seadanya sebagaimana kidang (rusa), (vi) topo ngrambang; menyendiri dalam hutan dan hanya makan tumbuh-tumbuhan, dan (vii) topo kungkum (ngambang); berendam (kungkum) atau ngambang di sungai dalam waktu tertentu ${ }^{44}$. Bentuk bertapa tersebut, bagi warga Samin, sesuai keinginan dan kemampuannya masing-masing, lazimnya dalam bentuk menjauhi keramaian dan makan seadanya (topo ngidang).

Selain topo juga melakukan meditasi yakni cara pendekatan diri pada Sang Pencipta atau makhluk halus dengan cara memohon. Meditasi memiliki berbagai bentuk yang dilakukan oleh mediator dengan menyatukan pikiran, mengatur napas, menahan napas atau tanpa menahan napas. Meditasi yang dilakukan dengan menahan napas dengan cara (i) awal meditasi; doa (mantera) dengan melakukan titik konsentrasi, (ii) menarik napas untuk memasukkan sebagian udara dalam paru-paru untuk persediaan saat melakukan meditasi, (iii) menahan napas; secara berulang-ulang yang menghasilkan berlapis-lapis gumpalan di sekitar tali pusar, dan (iv) melepas napas jika ketika menahan napas dirasa maksimal dengan perlahan-lahan agar paru-paru tidak terhentak ${ }^{45}$. Warga Samin dalam bermeditasi dengan bersila dan mengheningkan pikiran.

\section{Puasa Samin}

Puasa merupakan aktivitas prihatin dilakukan dengan lapar dan dahaga sebagai wujud memahami pihak lain yang miskin materi. Dengan puasa, diharapkan terjenihkan dari pikiran keruh

\section{${ }^{44}$ Ibid., 44.}

${ }^{45}$ Meditasi tanpa menahan napas dilakukan aliran Yoga yakni metode meditasi untuk menyatu dengan alam sekitarnya atau menyatukan diri dengan ciptaan Tuhan sebagai wujud percaya dengan ciptaan-Nya dan menyatukan diri dengan alam. Cara yang dilakukan (i) memilih lokasi meditasi yang memiliki kekuatan alam yang besar atau jauh dari keramaian dan jika di tempat terbuka dengan tujuan menyatu dengan alam sekitar, (ii) pelaksanaan; mencapai titik konsentrasi dengan bersila, keheningan pikiran adalah tujuan utama, dan (iii) akhir meditasi; jika mediator hilang konsentrasi. 
karena kesadaran diri pascaprihatin. Puasa ditafsirkan sebagai aktivitas berupa berbicara dengan tepat sesuai realitas. Hal ini mengilhami konsep prinsip dasar hidup Samin untuk tidak berbohong, tetapi jujur (ngepasno rembukan) terhadap siapa pun. Meskipun bagi sebagian warga Samin, melaksanakan puasa setiap bulan Suro dan hari kelahiran.

Bagi Samin dlejet, kata poso dipahami ngepasno roso utowo keno mangan, ora keno mlanggar aturan Samin arupo goroh, kudu jujur, lan ngepasno rembukan (menyelaraskan rasa atau boleh makan, tetapi tak boleh melanggar prinsip Samin berupa jangan bohong, harus jujur, tak boleh melanggar prinsip Samin, sebagai esensi berpuasa). Kata puasa (poso) juga diartikan ngepaske roso, rasa bersesama, memahami kondisi orang lain. Jika disakiti sakit, maka jangan menyakiti pihak lain atau mengoptimalkan di saat bersenggama. Penafsiran makna peribadatan sangat tergantung kemampuan diri penganut Samin dalam memahami pesan leluhurnya yang terwariskan secara lisan.

Bentuk Puasa Samin. Bentuk puasa Samin berupa puasa hari kelahiran, puasa suro, dan puasa pati geni. Sebelum melakukan puasa, disyaratkan mandi keramas (mandi besar) yakni menyiram air seluruh tubuh. Puasa hari lahir (weton) bertujuan mengenang hari kelahiran sekaligus media doa diri menuju kehidupan berikutnya agar diberi keselamatan. Sedangkan puasa suronan dilaksanakan masyarakat Samin di bulan Suro dilaksanakan satu di antara pilihan. Ada yang melaksanakan selama 40 hari, 21 hari, 7 hari, 3 hari, 1 hari 1 malam, sesuai kemampuannya. Puasa tersebut diakhiri dengan tidak tidur (melek) sehari semalam (ngebleng). Adapun puasa pati geni adalah ketika menjalankan puasa, menyendiri di suatu tempat yang tidak diperbolehkan melihat sinar apapun.

Konteks Jawa, menurut Pamungkas, puasa dipilah menjadi puasa mutih, ngebleng, weton, ngrowot, ngrame, mader bungkuk, mbisu, ngedan, lan mlaku. Puasa mutih adalah jenis puasa yang dilakukan spiritualis yang menginginkan adanya kemampuan dirinya dalam menghalangi penerimaan kekuatan gaib. Mengonsumsi makanan hanya ketika bersahur dan berbuka dengan nasi putih (jumlahnya ada yang menyatakan sekenyangnya atau hanya sekepalan tangan) dan tanpa lauk-pauk, hanya garam sebagai perasanya. 
Ada juga yang berpandangan bahwa diperkenankan makan (sebagaimana tidak puasa) setelah berbuka puasa. Sebelum berpuasa dilakukan mandi besar (keramas) disertai niat (tujuan) puasa. Puasa ngebleng dilakukan dalam waktu sehari semalam atau lebih tanpa mengkonsumsi makanan, minuman, dan lainnya. Sedangkan puasa weton adalah puasa yang dilakukan seseorang di hari kelahirannya (weton-nya) atau sehari sebelum atau setelah hari kelahiran. Puasa dilakukan karena percaya bahwa hari lahir membawa naas (sial), sehingga perlu ritual (puasa) dan sebagai bentuk penghormatan bahwa dalam diri seseorang 'didampingi'oleh hal gaib yang disebut sedulur batin, kakang kawah adhi ari-ari, guru sejati, dan keblat papat lima pancer. Puasa ngrowot bertujuan memperoleh ilmu tertentu. Dalam mengonsumsi (ketika sahur dan berbuka puasa) hanya dengan makanan yang alami biasanya dedaunan atau biji-bijian. Sedangkan puasa ngrame adalah puasa dilakukan dengan perjalanan (kaki) jarak jauh atau dekat tanpa bekal selama waktu tertentu.

Barang yang dikonsumsi mengandalkan belas iba orang lain atau barang yang ditemui berbentuk apapun. Puasa mader bungkuk dilakukan untuk mengurangi konsumsi makanan yakni hanya sekali makan, maksudnya, jika makan sesuatu tidak boleh menambah setelah menghabiskan satu buah atau satu porsi makanan, tidak diperbolehkan memakan makanan ringan (ngemii). Sedangkan puasa mbisu, ngedan, dan mlaku adalah puasa yang dilakukan dengan cara menyerupai orang bisu atau orang gila atau puasa dengan mengadakan perjalanan. Sedangkan puasa ngrame adalah puasa dilakukan dengan perjalanan (kaki) jarak jauh atau dekat tanpa bekal selama waktu tertentu. Barang yang dikonsumsi mengandalkan belas iba orang lain atau barang yang ditemui berbentuk apapun. Pilahan Ragil tersebut, puasa yang dilaksanakan warga Samin lazimnya puasa pada bulan Suro dan puasa hari kelahiran.

Tujuan dan Pantangan Puasa bagi Samin. Puasa bagi masyarakat Samin bertujuan pertama, ngurangi sandang-pangan sake untoro (mengurangi mengonsumsi makanan dalam waktu tertentu), mulai terbenam matahari hingga terbenamnya matahari hari berikutnya (semalam-sehari) dan diakhiri brokohan (slametan), khususnya puasa pati geni. Kedua, ngurangi roso 
(mengurangi rasa/bumbu dalam mengkonsumsi makanan berupa tidak disertakannya garam dalam makanan (ketika berbuka/sahur). Garam bermakna sumber rasa dalam makanan, sehingga tanpa garam diharapkan menggapai tujuan hidup (gegayuhan supoyo kasembadan) sebagai bentuk keprihatinan hidup dengan makanan yang sangat sederhana. Ketiga, netepno roso sejati (menetapkan/meneguhkan ajaran yang diwujudkan dalam perilaku (puasa) ${ }^{46}$. Keempat, menjalani kehidupan menggapai kebahagiaan bermodal perilaku (sesuai prinsip hidupnya) terciptanya kehidupan yang sejahtera. Kelima, puasa diharapkan mendapatkan ilmu (kanuragan, mantra). Keenam, menjadi sehat (dadi waras lan slamet), dan ketujuh, wujud prihatin (sireb) mensikapi kehidupan.

Puasa (sireh) terdapat pantangan (tidak mengonsumsi) (i) garam ketika berbuka dan sahur, (ii) buah-buahan, (iii) barang bernyawa, dan (iv) meninggalkan beras (woh dami). Meskipun warga Samin tidak memberi argumen, mengapa makanan tersebut ditinggalkan karena ajaran yang diwariskan leluhurnya dilaksanakan apa adanya (taken for granted). Jika pelaksanaan puasa dapat teraih dengan sukses, pada dasarnya meraih esok surut, sore nanggal (di pagi hari meninggal dunia, di sore harinya reinkarnasi) pada generasinya sehingga tercipta kehidupan yang baik dengan panjatan doanya mugo-mugo ketekan sejo, lan kekarepane. Asale wong, bali wong, seng becek kelakuane. Pak-pak bo, pak-pak bo. Ojo dadi, dadio kebo, dadio wong neh. Ojo mangan suket, mangano sego liwet. Ojo ngumbe banyu kali ngombeo banyu kendi.

\section{Tempat Peribadatan Samin}

Tempat beribadah/berdoa di tempat (kamar) tertentu (sanggar pamujan) yang juga digunakan untuk tidur. Adapun waktu terbaik adalah pada tengah malam (tengah wengi/tengah latri). Sedangkan waktu yang baik adalah esuk (pagi) atau sore. Adapun esensi berdoa (manembah) adalah mengakui diri bahwa terdapat

${ }^{46}$ Berupa rasane wong urip yeng digayuh ngemenno artikel (angan-angan dalam batin), partikel(menimbang-nimbang), kelakuan, ngeningno ati lan pikiran, gayuh apik tekan becik, manjinge ngilmu kanggo penganggo (tujuan manusia hidup jika dilaksanakan dengan ucapan dan tindakan didasari perasaan, sehingga 'ngilmu' akan meresap dalam kehidupan). 
(dzat) yang lebih tinggi yakni Tuhan (Yai). Dalam hal tempat peribadatan, dalam konteks kepercayaan dikenal sarana penghayat (srana) yakni alat bantu untuk memantapkan perilaku penghayat dan melaksanakan kepercayaan terhadap Tuhan Yang Maha Esa. Alat bantu tersebut dapat berupa perilaku (mengagungkan) atau simbolisasi atau lambang, seperti 'semangka' melambangkan anjuran 'ojo sumengko' (jangan bernafsu, bijaksanalah) atau bermakna pengayom (warna hijau di luar), juga bermakna brangasan (warna merah di dalam), dan berperilaku yang tidak baik (biji warna hitam di dalam) ${ }^{47}$.

Praktik beragama, warga Samin mengalami rembesan dari budaya sekitarnya yang non-Samin (Islam). Hal itu disikapi dengan pepatah Samin nepak ombae segoro (merespon kondisi zaman), seperti slametan (brokohan atau tingkeban) dengan ungkapan yang tidak sama dengan warga non-Samin ${ }^{48}$ atau pemulasaraan jenazah. ${ }^{49}$ Memegang prinsip Samin, warga Samin memiliki strategi memproteksi komunitasnya (nyiwer/disiwer). Maksudnya, bagi warga Samin, boleh mengajak orang lain untuk memeluk ajaran Samin dan pantangan keluar dari prinsip Samin (ora keno kowar-kawering kawerub). Ajakan tersebut sifatnya tidak mengikat (jenenge wong ora keno mekso awae liyan. Wong yeng kepengen

${ }^{47}$ Ensiklopedi Nasional Indonesia, 2004: 414.

${ }^{48}$ Poro sederek, kondo kulo ndiko sekseni, kulo gadah niat tiyang sekalian. Karep brokohi, kawitan tenggo wekasan. Brokohi sageto sae, ngenjange ngantos wingkeng. Kulo gadah niat brokohi turun kulo asale ngandut turune pun 7 sasi. Anane kulo brokohi sageto sae ngantos ngajenge lan wingkinge. Tiyang sekalian gadah niat brokobi. Kulo gadah niat sedulur kulo arane....Kulo brokohi kersane bantu tiyang sekalian sageto seger waras ngarep ngantos wingkeng. Danyange kulo brokohi. Kersane sae, ngajenge ngantos wingkinge. Kulo brokohi rinten kalayan ndalu, kersane bantu karepe tiyang sekalian.

${ }^{49}$ Tahapan pemulasaraan (merti) jenazah berupa (i) dimandikan (diadusi) sebagai simbol membersihkan pakaian/sandangan (jasad) atau tidak dimandikan (orak diadusi) karena si mayit saat hidup dianggap teguh prinsip kesaminan, (ii) dikafani (diulesi) dengan kain berwarna putih atau sebagian warga Samin dengan jarit (pakaian khusus perempuan), dan (iii) pemakaman (dikubur), tidak menggunakan lazimnya tata cara agama Islam (mayat tak ditalkin dan tak dihadapkan kiblat) atau tak sebagaimana cara agama Kristen (mayat tak dikenakan pakaian rapi, tidak berjas dan tak bersepatu). Ajaran Samin tak mengenal ziarah kubur atau khaul (ulang tahun wafat) atau slametan pascakematian. Hanya slametan di saat kematian (dino geblak). 
ngerti ora keno dipekso, ben tukul soko atine dewe. Hal ini berpijak pada prinsip Samin ora keno merekno kono, gumantung kemantepane dewe (tidak diperbolehkan iri dengan orang lain, tergantung keyakinan masing-masing). Usaha agar tidak terjadi pindah akidah, penanaman doktrin ajaran dengan model tuturan (wejangan) semenjak kecil oleh orangtua ${ }^{50}$ dan tokohnya sebagai strateginya. Kata 'orangtua' diartikan tuo yoiku tuwaneng akondo. Dalam realitanya, terdapat komunitas Samin yang keluar menjadi non-Samin, ada pula yang non-Samin menjadi warga Samin. Hengkang dari ajaran Samin menjadi Islam karena kahanan iku kanggo jatahe wong urip. Kabeh akal anglakoni. Ora biso disilai, wajibe menungso neng mbudi doyo gondelan neng ajaran Adam. Kahanan iku tumekane ora biso bareng, meski bergumanti (gantian), mergo kahanan donyo iku ibarat cokero manggilingan kenane owah lan gumingsir (ora langgeng).

\section{Konsep Ketuhanan Samin}

Masyarakat Samin mengaku beragama Adam yang di dalam ajarannya berprinsip bahwa etika adiluhung sebagai pegangan hidup. Esensi ajaran Adam dipegang teguh dalam prinsip ajaran dan menjauhkan prinsip pantangan kesaminan. Agama Adam sebagai perwujudan pengucap (tandeke neng pengucap, opo wae thukule soko pengucap), laku (perilaku), dan penganggo (pakaian). Pengucap bermakna jika berujar tidak berbohong dan konsisten dengan yang diucapkan. Laku diwujudkan dalam berperilaku tidak melanggar prinsip Samin dan melaksanakan poso. Ukuran kebenaran pemeluk agama jika aktivitasnya (tindak-tanduknya) benar. Penganggo adalah segala piranti (pakaian) yang dikenakan (digunakan) bersandar pada Adam. Keberadaan Adam dianggap orang pertama di dunia agar dunia sejahtera (donyo rejo) dan sebagai penguasa tunggal (Yai) ${ }^{51}$.

${ }^{50}$ Kata 'tua' juga bermakna tuo pitutur (dapat dijadikan sumber pengetahuan) dan bermakna tuo sembur bahwa orangtua juga harus bisa menjadi obat bagi yang sakit. Dapat pula bermakna tuwak yakni memenuhi kebutuhan anak dalam kehidupan pengetahuan beragama dan materi. Kata tua bukan berarti tuwas (tua usia, muda pengetahuan) atau tuwo jlangur yakni tidak tahu ajaran jika ditanya orang lain. Jika demikian, dikhawatirkan menjadi ngendi papan kari aran (hanya dikenang semata sebagai orangtua).

${ }^{51}$ Rosyid, Kodifikasi Ajaran, 54. 
Lahirnya Adam karena sabdo tunggal Yai, adanya Yai (Tuhan) karena adanya Adam (Ono iro ono ingsun, wujud iro wujud ingsun. Aku yo kuwe, kuwe yo Aku, wes nyawiji). Yai (yeng ngayabi samubarang kebutubane putu) putu duwe kewajiban, putu njaluk Yai kanti ngeningke cipto, roso, lan karso kang supoyo biso kasembadan sejo lan karep kanti neng, nheng, lan nep. Yai (Tuhan) bermakna dzat pemenuh hajat hidup makhluk, makhluk pun memiliki kewajiban. Jika makhluk memohon hanya kepada-Nya dengan mengheningkan cipta (semedi) dan berperilaku yang baik. Munculnya istilah "Adam" bermakna ugeman atau pegangan hidup. Adam juga sebagai bukti pemahaman warga Samin terhadap nama manusia pertama (Adam) ciptaan Tuhan (Yai) di dunia. Dalam ajaran agama Adam terdapat tradisi yang bermuatan ajaran etika hidup yang dipertahankan dalam pendidikan keluarga dengan tuturan/tradisi lisan dan tauladan oleh figur (botoh dan orangtua) ${ }^{52}$. Agama Adam mengajarkan ibadah. Peribadatan Samin berprinsip nindakno nengneng meneng, nenuwun marang yeng momong jiwo rogo, bakale keturutan pengangenane, melaksanakan konsentrasi dengan diam (semedi), memohon pada pemelihara jiwa raga, agar harapan terpenuhi. Prinsip ibadahnya wong urip kudu percoyo, ora keno mujo kayu-watu, adanya kesatuan (manunggaling kawulo marang gusti) dan adanya manusia karena adanya Tuhan. Kata 'Yai' bermakna kabeh yeng ngayahi (semua kebutuhan hidup manusia dicukupi Tuhan) dan keberadaan manusia sebagai putu Adam. Agama Adam tidak bersangkut-paut dengan proses pewahyuan karena mutlak berasal dari ide dasar leluhur/orang tua yang diikuti secara turun-temurun secara oral tradition kepada generasi Samin ${ }^{53}$.

Samin sebagai sebuah ajaran, pertama, mengedepankan nilainilai etika yang bersifat hubungan vertikal (manembab) yang esensinya mengakui diri bahwa ada yang lebih tinggi dalam kehidupan yakni Tuhan (Yai) dan ajaran horizontal berupa ikhlas, nrimo, tidak iri hati (benci) kepada siapapun, dan tidak ingin merugikan siapapun. Hal tersebut merupakan aplikasi prinsip dan pantangan hidup Samin. Kejujuran dianggap sebagai kunci menggapai ketenteraman hidup di manapun dan kapanpun. Kedua, ikhlas. Konsep ikhlas muncul diawali dari

\footnotetext{
${ }^{52}$ Rosyid, Samin Kudus, 21.

${ }^{53}$ Rosyid, Kodifikasi Ajaran, 55.
} 
prinsip bahwa 'semua adalah saudara' sehingga muncul gaya hidup (life style) yang bersifat permisif dan egaliter. Dengan motto: dhuwek ku yo dhuwek. mu, dhuwek mu yo dhuwekku, yen dibutubke sedulur yo diikhlaske (milikku juga milikmu, milikmu juga milikku, jika dibutuhkan ya diikhlaskan). Fondasi keikhlasannya berpijak dari prinsip barang apek ora usah diketok-ketokno, tetep apik yang menumbuhkan sikap saling tolong-menolong tanpa mengharapkan imbalan sedikitpun (ikhlas). Nrimo diwujudkan dengan tidak iri hati kepada siapapun. Konsep ini terilhami konsep Samin dalam prinsip hidup berupa ora srei-drengki (membenci) terhadap siapapun berpijak pada harapan untuk tidak konflik dengan sesamanya dan tidak ingin merugikan siapapun. Konsep ini berpangkal dari prinsip dasar hidup Samin berupa ora panesten-dawen (mencurigai) terhadap siapapun. Bagi masyarakat Samin, ajaran tersebut telah menjadi bagian dari urat nadi kehidupan sehari-harinya, meskipun perilaku pada dasarnya wilayah pribadi, sehingga kebenaran dan perilaku sangat pribadi tidak dapat digeneralisasikan.

Setelah memahami konsep ketuhanan agama Adam, muncul pertanyaan: apakah keyakinan warga Samin dapat dikategorikan agama? Pertama, persyaratan kepercayaan disebut agama menurut Durkheim yakni (i) adanya unsur penyatu secara kolektif bagi pengikutnya. Menurut Samiyono disebut sebagai doktrin/isi ajaran agama (system of belief) ${ }^{54}$, (ii) pemahaman bersama diungkapkan melalui sistem kepercayaan (beliefs and practices related to sacred things) yang dapat dilihat dalam aktivitas keagamaan. Sistem kepercayaan Samin, menurut Samiyono dilihat dalam tindakan keagamaan ${ }^{55}$, (iii) percaya terhadap yang sakral dan profan ${ }^{56}$. Pembeda antara sakral dan profan sangat sulit, menurut Samiyono karena perbedaan cara pandang terhadap yang sakral dan yang profan dalam diri penganut Samin. Hal ini tidak ada standar penentu yang sakral dan yang profan, tetapi hanya berdasarkan ajaran yang diberikan oleh sesepuh Samin.

${ }^{54}$ David Samiyono, Struktur Sosial dan Agama Masyarakat Samin di Sukalila (Salatiga: Program Pascasarjana UKSW, 2010), 102.

55Ibid., 102.

${ }^{56}$ Emile Durkheim, The Elementary Forms of The Religious Life (New York: The Free Press Mahatma Gandhi, 1963), 62. 
Individu dapat menentukan sakral atau tidak berdasarkan pengalaman keberagamaannya ${ }^{57}$.

Kedua, dalam konteks agama, menurut King, agama Adam yang dianut masyarakat Samin berbeda dari praktek sinkretisme yang lazim terjadi di antara masyarakat Jawa. Hal ini karena agama Samin hampir tidak memberi tempat bagi praktek ajaran agama lain. Meskipun demikian, menurut King, agama Samin tetap harus dilihat dalam konteks kepercayaan masyarakat Jawa yang terpusat di seputar aktivitas agrikultural (pertanian). Tetapi, kepercayaan tradisional Jawa digunakan masyarakat Samin sebagai sarana memperkuat solidaritas dan menangkal pengaruh dari luar. Masyarakat Samin menolak segala bentuk ajaran dari luar, baik Islam maupun Hindu dan menghendaki ajaran yang murni agama Jawa dan bebas dari pengaruh asing dalam bentuk apapun. Konsekuensinya mereka menjaga jarak dengan penduduk Jawa yang telah memeluk agama ${ }^{58}$. Hal ini terjadi pada konteks masa lalu. Realitasnya kini, komunitas Samin membaur bersama lingkungannya yang non-Samin. Bahkan sebagaimana terjadi di Kudus, warga Samin dipercaya sebagai Ketua RT, ada pula Ketua RW yang warganya Samin dan non-Samin. Ada pula warga Samin Kudus menjadi panitia pembangunan masjid dan sebagai donatur pembangunan masjid.

Ketiga, fungsi agama bagi pemeluknya di antaranya sebagai pengendali kebebasan manusia, memelihara hak asasi, membantu lahirnya kesejahteraan, ketenteraman, dan kebahagiaan individu ${ }^{59}$.

Ciri agama menurut Ali (i) agama merupakan suatu sistem tauhid (keimanan/keyakinan) terhadap eksistensi sesuatu yang absolut (mutlak) di luar diri manusia yang merupakan causaprima atau penyebab pertama daripada segala sesuatu termasuk dunia dengan segala isinya, (ii) agama merupakan satu sistem ritual atau peribadatan/penyembahan dari manusia kepada sesuatu yang diberi predikat Yang Absolut (Mutlak) atau Causa-

57 Samiyono, Struktur Sosial, 103.

${ }^{58}$ Victor T King, Some Observations on the Samin Movement of North-central Java (Leiden: Bijdragen tot de Taal-, Land- en Volkenkunde 129, 1973), 457.

${ }^{59}$ Abdullah Ali, Agama dalam Ilmu Perbandingan (Bandung: Nuansa Aulia, 2007), 27. 
Prima, dan (iii) agama merupakan satu sistem nilai atau norma, kaidah yang menjadi pola hubungan manusiawi antara sesama manusia dan pola hubungan dengan ciptaan lainnya yang seirama dengan sistem tauhid dan ritual ${ }^{60}$. Berpijak dari fungsi dan ciri agama tersebut, keyakinan Adam bagi warga Samin dapat dikategorikan sebagai agama.

\section{Perbandingan antara Tuhan dalam Islam dan Tuhan dalam Agama Adam}

Untuk memahami esensi dasar pemahaman tentang Tuhan dalam Islam, naskah ini memfokuskan kajiannya berpijak pada pesan surat al-Ikhlaṣ. Surat al-Ikhlaṣ turun sebanyak 4 ayat di Kota Makkah. Sebab turunnya ayat (asbab an-nuгul) ayat tersebut dilatarbelakangi ancaman pembunuhan terhadap diri Nabi saw karena kiprah Nabi mendakwahkan agama Islam pada bangsa Quraysh di Makkah. Pada suatu kesempatan, kafir Quraysh mengadakan forum pertemuan di Darun Nadwah yang memutuskan membuka sayembara kepada siapa saja yang mampu menangkap dalam kondisi hidup atau mati Nabi saw dan dibawa di hadapan tokoh Quraysh, mendapat hadiah berupa 100 unta berwarna merah dan 100 kuda arab. Seorang kafir Quraysh bernama Suraqah memberanikan diri memenuhi sayembara tersebut. Upaya penangkapan Suraqah pada diri Nabi saw dilakukan dengan mengendarai kuda. Ketika Nabi saw dalam perjalanan, Suraqah menghunuskan pedang dan akan memenggal kepala Nabi, tetapi seketika itu, kuda Suraqah terplanting dan Suraqah terjatuh sebelum memenggal Nabi saw, tatkala itu Nabi menolongnya. Pertolongan Nabi yang diberikan pada Suraqah bukan timbul rasa terima kasih apalagi iba, tetapi kebringasan Suraqah semakin memuncak dengan menghunus pedang dan berusaha membunuh lagi. Akan tetapi, nyawa Nabi saw selalu mendapat perlindungan dari Allah swt sehingga usaha pembunuhan Suraqah yang kedua tetap gagal karena terjatuh dari kuda yang kedua. Kondisi terjatuh tersebut, Nabi tetap menolongnya sehingga Suraqah menanyakan kepada Nabi: wahai Muhammad, beritahukanlah kepadaku siapa Tuhanmu? Apakah

${ }^{60}$ Ibid., 17. 
Tuhanmu terbuat dari emas atau perak? Sebelum nabi menjawab, turunlah surat al-Ikhlas sebagai jawaban atas pertanyaan Suraqah berupa jawaban: "Katakan wahai Muhammad bahwa Allah swt adalah Esa, Allah tempat berlindung, tidak memiliki keturunan (tak beranak) dan tidak diperanakean (tidak beribu-bapak), dan tak satupun yang setaranya dengan-Nya.

Pesan 4 ayat dalam surat al-Ikhlaṣ tersebut bila disandingkan dengan konsep Tuhan pada agama Adam, menurut penulis terdapat sisi kesamaan. Kesamaan ini bukan berarti terjadi keunggulan atau merendahkan satu konsep Tuhan di antara Islam dan agama Adam, tetapi konsep yang berpijak pada tataran ilmiah yang kebenarannya berpijak pada rasio. Kesamaan itu adalah: pertama, Allah swt (dalam Islam) dan Yai (dalam agama Adam) keduanya berkedudukan sebagai tempat berlindung (ash-shomad) dan tempat memohon kehidupan makhluk-Nya. Kedua, kata 'Adam' oleh orang Samin dipahami sebagai orang yang pertama kali di dunia (inggih kawitan utawi pisanan tiyang ingkang ten ngalam ndonyo). Keberadaan Nabi Adam as tertuang dalam pesan Qs. Ali 'Imrān: 59 "Allah ciptakan Adam dari tanah, jadilah seorang manusia". Qs. al-Baqarah (2):35 "Hai Adam hunilah surga", ayat 36 "Adam turun di dunia". Adam adalah manusia pertama ciptaan Allah dari tanah, diciptakan secara langsung dengan ditiupkan ruh tak melalui fase bentuk pascakelahiran. Riwayat Ibnu Abbās dan TTabrān̄̄ dari 'Umar, Nabi Adam diturunkan Allah (di dunia) di India dan wafat di Syria (Suriah). Menurut al-Ṭabari, Adam diturunkan di India, puncak Gunung Everets (8.884 mdpl) Himalaya. Menurut Sami bin 'Abdullāh al-Maghluth, Adam hidup sekitar tahun 5872 SM dan wafat 4942 SM. Ada yang menyatakan Adam diturunkan dari surga (tiba) di Dajna, antara Makkah dan Ṭaif atau Adam diturunkan di Bukit Șafa dan Hawa (isteri Nabi Adam) di Marwah. Adam wafat dan dimakamkan di kaki Gunung Abu Qubays, Makkah. Ketiga, kekuasaan Allah bagi muslim dan kekuasaan Yai bagi Samin tak ada yang menandingi.

\section{Catatan Akhir}

Memahami konsep Tuhan pada agama yang dipeluk orang lain membuahkan hikmah berupa menyadari bahwa setiap ajaran 
agama mengajarkan esensi Tuhan, sebagaimana konsep Tuhan pada agama Adam yang dipeluk komunitas Samin. Kesadaran ini perlu ditumbuhkembangkan agar antarpemeluk agama tidak saling mengolok-olok sebagai bentuk awal terjadinya konflik. Bahkan harapan terwujudnya pemeluk agama yang bertoleransi dengan pemeluk agama lain akan terwujud manakala antarpemeluk agama tidak merasa dirinya atau agamanya yang memiliki konsep Tuhan.

Pesan surat al-Ikhlaṣ memberikan pelajaran pada kita bahwa keberadaan Allah swt sebagai Dzat Yang Esa, keberadaannya ada dengan sendirinya, dan dijadikan tempat berlindung semua makhluknya. Begitu pula pemahaman komunitas Samin terhadap keberadaan Tuhannya yakni Yai. Ajaran Islam dan agama Adam mengajarkan bahwa diri Adam merupakan makhluk (manusia) Tuhan yang pertama menghuni bumi. Dalam Islam keberadaan Nabi Adam as juga sebagai khalifah di bumi (pengelola alam). Wa al-Lāh a lam bi al-sawāb.

\section{Daftar Pustaka}

Ali, Abdullah. 2007. Agama dalam Ilmu Perbandingan. Bandung: Nuansa Aulia.

Durkheim, Emile. 1963. The Elementary Forms of The Religious Life. New York. The Free Press Mahatma Gandhi.

Endraswara, Suwardi. 2003. Budi Pekerti dalam Budaya Jawa. Yogyakarta: Hanindita.

Hidayat, Komarudin. Agama itu Ageman. Kompas, 22 Oktober 2011.

Kardi, Hardjo. 1996. Riwayat Perjuangan Ki Samin Surosentiko. Tanpa Penerbit. Tanpa Kota Terbit.

Kahmad, Dadang. 2000. Metode Penelitian Agama Perspektif Ilmu Perbandingan Agama, Bandung: Pustaka Setia.

Norkhoiron. "Dari Buku ke Buku Sambung Menyambung Menjadi Samin", Majalah Kebudayaan. Desantara: Jakarta. edisi 6/tahun II/2002.

Purnomo, Sucipto Hadi. "Mengontrol yang Gung-Binathara", Suara Merdeka, 26 Juni 2011. 
Rosyid, Moh. 2008. Samin Kudus Bersahaja di Tengah Asketisme Lokal. Yogyakarta: Pustaka Pelajar. . 2010. Kodifikasi Ajaran Samin. Yogyakarta: Kepel

Press.

Sigar, Edi. 1998. Provinsi Jawa Tengah. Jakarta: Pustaka Delapratasa.

Sastroatmodjo, Soerjanto. 2003. Masyarakat Samin Siapakah Mereka? Yogyakarta: Narasi.

Susetya, Wawan. 2007. Hawa Nafsu Orang Jawa. Yogyakarta: Narasi.

Samiyono, David. 2010. Struktur Sosial dan Agama Masyarakat Samin di Sukalila. Salatiga: Program Pascasarjana UKSW Salatiga.

T King, Victor. 1973. Some Observations on the Samin Movement of North-Central Java. Bijdragen tot de Taal-, Land- en Volkenkunde 129 (1973) Nomor 4, Leiden.

Winarno, Sugeng. 2003. Samin: Ajaran Kebenaran yang Nyeleneh dalam Agama Tradisional Potret Kearifan Hidup Masyarakat Samin dan Tengger. LKiS: Yogyakarta.

Wijoyo, Pramugi Prawiro. 2011. Giyare Kaki Samin Surosentiko Bab Lakon 'Sikep'Winongko Paugerane Urip Kang Demunung. Tanpa penerbit. 